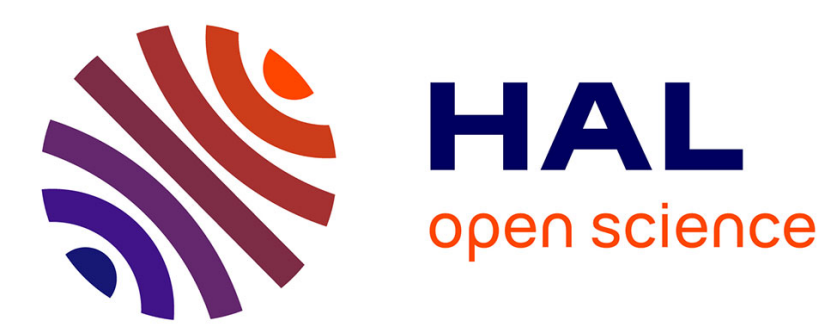

\title{
Enhancer and competitive allosteric modulation model for G-protein coupled receptors
}

Daniele Pietra, Alice Borghini, Maria Cristina Breschi, Anna Maria Bianucci

\section{To cite this version:}

Daniele Pietra, Alice Borghini, Maria Cristina Breschi, Anna Maria Bianucci. Enhancer and competitive allosteric modulation model for G-protein coupled receptors. Journal of Theoretical Biology, 2010, 267 (4), pp.663. 10.1016/j.jtbi.2010.08.024 • hal-00637806

\section{HAL Id: hal-00637806 https://hal.science/hal-00637806}

Submitted on 3 Nov 2011

HAL is a multi-disciplinary open access archive for the deposit and dissemination of scientific research documents, whether they are published or not. The documents may come from teaching and research institutions in France or abroad, or from public or private research centers.
L'archive ouverte pluridisciplinaire HAL, est destinée au dépôt et à la diffusion de documents scientifiques de niveau recherche, publiés ou non, émanant des établissements d'enseignement et de recherche français ou étrangers, des laboratoires publics ou privés. 


\section{Author's Accepted Manuscript}

Enhancer and competitive allosteric modulation model for G-protein coupled receptors

Daniele Pietra, Alice Borghini, Maria Cristina Breschi, Anna Maria Bianucci

PII:

S0022-5193(10)00447-9

DOI: doi:10.1016/j.jtbi.2010.08.024

Reference: YJTBI 6128

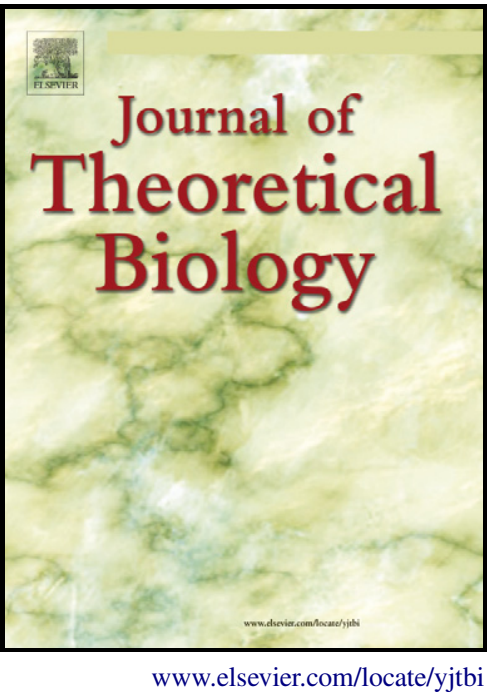

To appear in: Journal of Theoretical Biology

Received date: $\quad 10$ March 2010

Revised date: 4 August 2010

Accepted date: 20 August 2010

Cite this article as: Daniele Pietra, Alice Borghini, Maria Cristina Breschi and Anna Maria Bianucci, Enhancer and competitive allosteric modulation model for G-protein coupled receptors, Journal of Theoretical Biology, doi:10.1016/j.jtbi.2010.08.024

This is a PDF file of an unedited manuscript that has been accepted for publication. As a service to our customers we are providing this early version of the manuscript. The manuscript will undergo copyediting, typesetting, and review of the resulting galley proof before it is published in its final citable form. Please note that during the production process errors may be discovered which could affect the content, and all legal disclaimers that apply to the journal pertain. 
Enhancer and Competitive Allosteric Modulation Model for G-protein Coupled Receptors

Daniele Pietra $^{\mathrm{a}}$, Alice Borghini ${ }^{\mathrm{b}}$, Maria Cristina Breschi ${ }^{\mathrm{c}}$, Anna Maria Bianucci $^{\mathrm{b}}$

${ }^{a}$ Dipartimento di Medicina Interna - University of Pisa - Via Roma, 67 - 56126 Pisa Italy

${ }^{\mathrm{b}}$ Dipartimento di Scienze Farmaceutiche - University of Pisa - Via Bonanno, 6 - 56126 Pisa - Italy

${ }^{\mathrm{c}}$ Dipartimento di Psichiatria, Neurobiologia, Farmacologia e Biotecnologie - University of Pisa - Via Bonanno, 6 - 56126 Pisa - Italy

\section{Authors' e-mail addresses}

Daniele Pietra: daniele2674@,yahoo.it

Alice Borghini: aliceborghini1974@yahoo.it

Maria Cristina Breschi: breschi@,farm.unipi.it

Anna Maria Bianucci: bianucci@dcci.unipi.it, bianucci@,farm.unipi.it

\section{Corresponding author}

Dr. Anna Maria Bianucci

Dipartimento di Scienze Farmaceutiche - Università di Pisa

Via Bonanno, 6 - 56126 Pisa (Italy) 
Tel. +39050 2219544

Fax +39050 2219605

e-mail: bianucci@dcci.unipi.it, bianucci@,farm.unipi.it 


\begin{abstract}
A new mathematical model, referred to as Enhancer and Competitive Allosteric Modulator (ECAM) model, developed with the aim of quantitatively describing the interaction of an allosteric modulator with both enhancer and competitive properties towards G-protein coupled receptors is described here. Model simulations for equilibrium (displacement-like, saturation-like), and kinetic (association, dissociation) binding experiments were performed. The results showed the ability of the model to interpret a number of possible ligand-receptor binding behaviors. In particular, the binding properties of PD81723, an enhancer and competitive allosteric modulator for the adenosine $A_{1}$ receptor, were experimentally evaluated by radioligand binding assays and interpreted by the ECAM model. The results also offer a theoretical background enabling the design and optimization of compounds endowed with allosteric enhancer, competitive, agonist, antagonist, inverse agonist properties.
\end{abstract}

\title{
Keywords
}

Ligand-receptor interactions, Allosterism, Drug screening, PD81723 


\section{Introduction}

G protein-coupled receptors (GPCRs) represent a large family of transmembrane receptors. Their importance arise from their ubiquitous expression, their molecular diversity, their ability to interact with a huge number of ligands, such as olfactory stimulatory molecules, photons, hormones, neurotransmitters, amino acids, peptides, and others. Given the wide range of physiological roles played by GPCRs, it should not be surprising that they currently account for approximately $50 \%$ of small-molecule drug targets and represent the largest class of tractable therapeutic targets.

According to the most recent classification, GPCRs are divided into five families: glutamate, rhodopsin-like, adhesion, frizzled/taste and secretin-like receptors (Bjarnadóttir et al., 2006). This classification is purely based on phylogenetic criteria, according to the so-called GRAFS system (Fredriksson et al., 2003; Schiöth and Fredriksson, 2005).

For most known rhodopsin-like receptors the endogenous ligands bind the receptor at the orthosteric site, which is a domain located inside the bundle arising from a cavity formed by the seven transmembrane helices, when the ligand is a small molecule. If it has larger size, the site is located, instead, nearer the outer membrane side.

When the ligand binds the orthosteric site, receptor activation is induced and the signal transduction starts. Allosteric compounds, instead, bind sites, the allosteric sites, that are spatially distinct from the orthosteric one so that they do not mediate their effects by physical occupancy of the same cavity. Thus, the orthosteric site is not directly involved when an allosteric compound binds the receptor, but the allosteric compound induces in the receptor molecule a reversible conformational change, an allosteric transition, that indirectly modifies the binding properties of the orthosteric site. As a consequence, 
these modifications may confer to the receptor itself new functional properties. In particular, allosteric compounds may determine a modulation of the orthosteric ligand binding, by acting cooperatively with it. A positive cooperativity exists when a ligand molecule increases the affinity of receptor towards other molecules of the same ligand or towards different ligands, while such an affinity is decreased in the case of a negative cooperativity. An allosteric modulator showing positive cooperativity is called enhancer or positive allosteric modulator, while an allosteric modulator showing negative cooperativity is called negative allosteric modulator.

Allosteric modulation of GPCRs has opened a wide range of new therapeutic possibilities, since they may be exploited for example to enhance receptor selectivity, to direct tissue selectivity, or to reduce side effects. The identification of a ligand acting as competitive ligand interacting with the orthosteric site, or one acting as allosteric modulator, as well as the estimate of their affinity parameters play a key role in drug design and discovery. The orthosteric ligands allow the use of structure-based techniques, since they interact with target receptors in relatively well-known regions. On the contrary, the search for allosteric modulators is usually approached by means of functional assays, since they may bind GPCRs at very different areas, although the recent description of high resolution crystal structures of GPCRs (Rassmussen et al., 2007; Jaakola et al., 2008) may also promote a rational design of allosteric modulators.

From an experimental point of view, affinity parameters such as $\mathrm{pEC}_{50}$ or $\mathrm{pK}_{\mathrm{i}}$, that are routinely measured for orthosteric compounds, are not sufficient to estimate the affinity of an allosteric modulator and to correlate this affinity value with the efficacy of the modulator itself. Indeed, since an allosteric modulator interacts with the receptor by a non competitive mechanism, the simple model commonly used to derive the property 
values is not suitable anymore.

Thus, in order to understand the behavior of an allosteric modulator in biological assays, different parameters referring to the efficacy of the modulator are needed. Over the years, a number of more or less complex mathematical models have been developed, with the aim of obtaining such parameters. The most known and most commonly used model, able to explain the effects of compounds acting by allosteric mechanisms, is the Allosteric ternary complex model (Eherlet, 1988) (Fig. 1A). It accounts for two ligands, A and $\mathrm{B}$, binding different sites of the same receptor, $\mathrm{R}$, for the resulting binary complexes, AR and RB, and for ternary complex ARB. However, this model is not able to explain some behaviors of allosteric modulators. On the other hand, this model is quite simple, as it is only based on three thermodynamic constants. That makes it easy to deal with, when used for the interpretation of binding assay results involving allosteric modulators.

Other and more sophisticate models have been proposed over the time with the aim of interpreting more complex behaviors. As an example, the Extended ternary complex model (Samana et al., 1993) has been proposed, where receptors coexist in an inactive (R) and an active $\left(\mathrm{R}^{*}\right)$ state, according to an equilibrium constant J. The ligand $\mathrm{H}$ may bind the receptor in both states ( $\mathrm{R}$ and $\mathrm{R}^{*}$ ), but only the active state may bind G-protein (G) (Fig. 1B). In another model, the so-called Allosteric two state model, the free receptor exists in inactive and active forms, $\mathrm{R}$ and $\mathrm{R}^{*}$, as in the two-state model. The two ligands, A and B, bind different sites on the receptor and may discriminate between the two states and between the free receptor and the binary complex (Hall, 2000) (Fig. 1C).

However, the above-mentioned models are still not able to intepret unusual behaviors 
that may be shown in radioligand binding assays. In particular, none of said models can deal with compounds which are able to interact both allosterically and competitively with GPCRs. An example is the compound named "PD81723", detailed in the following, which interacts with the adenosine $\mathrm{A}_{1}$ receptor both as an enhancer and as a competitive allosteric modulator (Bruns and Fergus, 1990). A modulator such as PD81723 may be in competition with the radioligand to bind the orthosteric site, while modulating the binding of the radioligand via an allosteric interaction with the same receptor. A further model was then proposed (Christopoulos and Kenakin, 2002), and it is illustrated in Fig. 1D. Along the text, this model will hereinafter referred to as the "CK model". Details about the parameters characterizing these models are defined in the relevant bibliographic references (Eherlet, 1988; Samana et al., 1993; Hall, 2000; Christopoulos and Kenakin, 2002).

As it can be deduced from the observation of these models, only the CK model is able to explain some behaviors of allosteric modulators, such as the bell-shaped curves and the very steep inhibition curves, which may be found in certain competition-like binding experiments. Examples of ligand-binding interactions showing these behaviors are the binding of $\mathrm{PD} 81723$ at the adenosine $\mathrm{A}_{1}$ receptor, and the binding of mehtylisobutylamiloride (MIA) at the dopamine $\mathrm{D}_{2}$ receptor (Hoare and Strange, 1996), respectively.

The increasing complexity of said models implies the involvement of a quite high number of parameters and thermodynamic constants. For instance, the Allosteric two state model is based on 7 thermodynamic constants. At present, the number of such parameters is too high for being determined both carefully and with limited costs, also when high-throughput screening (HTS) methodologies for radioligand binding assay are 
exploited.

Simple models able to assess whether or not a compound acts as an enhancer and competitive allosteric modulator towards a given receptor, and to evaluate its affinity parameters towards said receptor are currently lacking. For this reason, this work was aimed at formulating a mathematical model enabling the evaluation of kinetic and equilibrium binding properties of an enhancer and competitive allosteric modulator towards GPCRs.

Indeed, this model allows considering that competitive features may be associated to an allosteric modulator, at a more or less marked extent. Furthermore, the complexity of such an extended model also allows considering all the receptor forms, associated or not to G-protein. A restricted form of the model, obtained by ignoring the G-protein interactions, can be easily applied for routine analysis of the results obtained from receptor binding assays. Such a restricted model, that involves only 4 thermodynamic constants and 8 kinetic constants, is able to explain several complex behaviors in both equilibrium and kinetic experiments, such as bell-shaped curves in competition-like experiments. It is also capable of providing parameters associated to the efficacy of the modulator which, in turn, may be correlated to the chemical structure of the modulator itself. On the other hand, the model developed in its more complex form (which takes the G-protein into account), further extends the interpretation capability for a number of allosteric modulator behaviors that can be observed as a result of laboratory experiments. 


\section{Model formulation}

It is known that GPCRs may exist in both G-protein bound and G-protein unbound forms, which show different affinities towards the ligands. In particular, agonists possess high affinity for the receptor form bound to G-protein and low affinity for the unbound receptor form. On the contrary, antagonists possess low affinity for the receptor form bound to G-protein and high affinity for the receptor unbound form. Based on the above mentioned knowledge, a model, named the Enhancer and Competitive Allosteric Modulator (ECAM) model, was formulated, which represents the interaction of an allosteric modulator, with both enhancer and competitive properties, towards a GPCR and a further ligand thereof.

In the model, a generic ligand (L), which can be an endogenous one, a labelled one, such as a radioligand or a fluorescent ligand, an agonist, an antagonist, can exist in either a bound or unbound form with respect to the orthosteric binding site of the receptor $(\mathrm{R})$. Another ligand $(\mathrm{A})$, defined as an allosteric and competitive modulator, may bind an allosteric site on $\mathrm{R}$, due to its allosteric properties, as well as to the orthosteric site, due to its nature which may also be competitive.

When a molecule of the species A interacts with the receptor R, A may bind the orthosteric or allosteric site, depending on its relative affinity towards the two sites, resulting in the formation of an RA complex. If A binds the orthosteric site and a second molecule of A may interact with the RA complex, binding the allosteric site, the $\mathrm{RA}_{2}$ complex takes place. On the other hand, when the orthosteric site of $\mathrm{R}$ is already occupied by L (RL complex), the modulator A may only bind the allosteric site, resulting in the formation of RLA complex. 
When a ligand (either L or A) is inside the orthosteric site, the occupancy of the allosteric site by A may also decrease the dissociation of the ligand from the receptor. Moreover, when the system also contains the relevant G-protein, the receptor $\mathrm{R}$ and any of its complexes with A and/or L (RL, RA, RLA, RA 2 ) may further interact with the Gprotein itself, giving rise to the GR, GRL, GRA, GRLA, GRA 2 complexes. When $\mathrm{R}$ is coupled to the G-protein, it may show affinity values for L and/or A different from values showed by the uncoupled receptor. All the above mentioned species, the equilibria they are involved in, and the thermodynamic equilibrium constants are summarized in Fig. 2. The detailed description of the characteristics of each species and the thermodynamic equilibrium constants, as well as the derivation of the equilibrium binding model, are reported in Appendix. The kinetics of an analogous system, in the absence of G-protein but in the presence of a further inhibitor I, which competes with the radioligand $\mathrm{L}$ and which may be allosterically modulated by $\mathrm{A}$, is illustrated in Fig. 3.

\section{Model behavior}

Model simulations for equilibrium (displacement-like, saturation-like), and kinetic (association, dissociation) binding experiments were performed.

The behavior of the model was analyzed by simulation of radioligand binding experiments, both in the presence and in the absence of a modulator. That enabled exploring the performances of the model when its parameter values are close to values commonly retrieved in the prior art of the above experimental technique. The following conditions were chosen for simulations: a simple system not involving any G-protein (Fig. 2B), a receptor completely coupled to G-protein (Fig. 2C), and a more complex 
system characterized by a G-protein not completely bound to receptor (Fig. 2A), both for displacement-like binding assay and saturation-like binding assay simulations.

A simple system not involving any G-protein was considered for simulations of kinetic association (Fig. 3B) and dissociation (Fig. 3A) experiments.

It should be pointed out that the experiment simulations presented in this work are intended only to bring qualitative information about the kind and the general shape of the resulting curves. The reader should also keep in mind, when performing an experiment, that, if he/she observes a curve different from the ones expected for competition phenomena, obtaining, instead, a trend recalling the ones presented herein, he/she should consider that the analyzed compounds could behave as ECAM modulators. It is worth to highlight at this point that the plots reported in this paper refer to some significant parameters well suited for simulations. The ratios between parameters used herein were just aimed at supplying examples of plausible values for initial parameters to be used in order to apply the present model in fitting actual experimental data.

\section{$\underline{\text { Displacement-like binding assay simulations }}$}

This kind of experiment was performed by keeping at a constant value the initial concentrations of receptor or G-protein-receptor complex, as well as the initial concentrations of the radioligand L, while the initial concentration of the allosteric modulator was changed. At the beginning, a system including a radioligand L, a receptor $\mathrm{R}$, and a modulator $\mathrm{A}$, under conditions approaching to equilibrium, and not allowing depletion of both L and A by the receptor (Fig. 2B), was considered. Such a system is represented by equation (Eq. 28) in Appendix. The parameters chosen to 
illustrate the model behavior under these conditions are given in Table 1, while the related plots are shown in Fig. 4. Similar considerations should be assumed for an analogous system where the receptor $\mathrm{R}$ is completely associated to the relevant $\mathrm{G}$ protein (Fig. 2C), which can be described by equation (Eq. 29) in Appendix.

The system involves a radioligand at a concentration equal to its $\mathrm{K}_{\mathrm{d}}$. That implies, when the modulator is not present, a receptor occupancy of $50 \%$, which is required for enabling instead the optional enhancer-positive effects (curve with an increasing trend), or negative-competitive effects (curve with a decreasing trend), on radioligand binding when the modulator is present. It represents the initial value of disintegrations per minute (dpm) for each curve.

The enhancer-positive effects are found when the complexed forms of the receptor with the radioligand, RLA and RL, take place in a dominant amount. At a given concentration of a given radioligand, they depend on $\mathrm{K}_{1}$ and $\mathrm{K}_{4}$. On the contrary, negative-competitive effects depend on the dominant formation of the non-radioactive species of the receptor, that is $\mathrm{RA}$ and $\mathrm{RA}_{2}$, thus they depend on the thermodynamic constants $\mathrm{K}_{2}$ and $\mathrm{K}_{3}$. It should be noted that the extent of a curve, towards the direction of higher modulator concentrations, is limited by the solubility of the modulator itself in the assay medium.

In plots of Figs. 4A, 4B, and 4C the positive enhancer effects are represented. The trends may take the shape of a sigmoidal curve with an increasing trend (4A), a bellshaped curve with a more or less marked maximum (4B), or a sigmoidal curve with an increasing trend which reaches a plateau, and then decreases (4C).

The sigmoidal curve with an increasing trend in Fig. $4 \mathrm{~A}$ is observed when $\mathrm{K}_{4}$ is much lower than both $\mathrm{K}_{2}$ and $\mathrm{K}_{3}$, so that the equilibria are shifted towards the formation of $\mathrm{RL}$ 
and RLA complexes, and the formation of RA and $\mathrm{RA}_{2}$ species is not significant. In this case, when the modulator concentration is sufficiently high, the curve reaches a plateau corresponding to the fully associated receptor. Even with different positive-enhancer modulators, the plateau height will not change, since it only depends on the total receptor amount. However, with changes in $\mathrm{K}_{4}$ (in particular with a decrease in the $\mathrm{K}_{4}$ value) the concentration for which the positive effects appear will decrease, and the curve will be shifted to the left. On the contrary, when $\mathrm{K}_{4}$ increases, the concentration for which the positive effects appear will increase. In this case, the curve will be shifted to the right.

When the sigmoidal curve with an increasing trend in Fig. 4A is analyzed in a range towards hypothetical infinite modulator concentrations, the curve starts decreasing after the plateau, as it happens in the case of Fig. $4 \mathrm{C}$. This is because the RA and $\mathrm{RA}_{2}$ complexes begin to appear, since the concentration of A becomes much higher than $\mathrm{K}_{3}$. In this case, the increasing step only represents the initial portion of the curve (4A). The positive effects occur when $\mathrm{K}_{4}$ is lower than $\mathrm{K}_{2}$, and a small difference between those two constants is enough to observe a small increase of the curve. In particular, when $\mathrm{K}_{4}$ is lower than $\mathrm{K}_{2}$, and, at the same time, $\mathrm{K}_{3}$ is sufficiently low, the curve may not to reach any plateau, taking instead a more or less marked bell-shape (4B).

In plots of Figs. 4D to $4 \mathrm{~F}$ the displacement effects are higher than (4D and $4 \mathrm{E})$ or comparable to $(4 \mathrm{~F})$ the positive enhancer effects. When $\mathrm{K}_{4}$ is much higher than $\mathrm{K}_{2}$, that is when the equilibria are shifted towards the formation of the RA species, and the other equilibria are negligible, a typical competition curve characterized by a Hill coefficient $=1$ (4D) is obtained. When the $\mathrm{RA}_{2}$ formation, which is controlled by $\mathrm{K}_{3}$, is negligible, while the formation of RL and RLA species is comparable to the RA formation, the 
positive effects are equal to the negative ones. That results in a neutral effect, which leads to an horizontal straight line (4F). On the other hand, a steep curve is observed when $\mathrm{K}_{2}$ is comparable to $\mathrm{K}_{4}$, but $\mathrm{K}_{3}$ is lower than these two constants: in this case the $\mathrm{RA}_{2}$ formation is no longer negligible.

Other kinds of curves, characterized by decreasing trends due to $\mathrm{K}_{4}$ value higher than $\mathrm{K}_{2}$, may be observed. They can, for instance, show a trend which does not reach the value of aspecific binding (4G), may take broad shapes $(4 \mathrm{H})$, or show duplex trends (4I). That can be observed when the positive effects counteract the negative ones, at a different extent. The detailed shape of the curve depends on the relative values of the parameters (see Figs. $4 \mathrm{G}$ to $4 \mathrm{I}$ ). In the case of Fig. $4 \mathrm{G}$, the second decreasing step is expected to occur at higher concentrations.

When the system also involves a G-protein (Fig. 2A) the concentration of which doesn't allow its depletion by the receptor $(\mathrm{R})$, the system behavior may also be described by equation (Eq. 27). Other parameters that may affect the height of the curves are mentioned below: (a) the ratio between total concentration of G-protein and its dissociation constant from receptor $\left(\mathrm{G} / \mathrm{K}_{5}\right)$; (b) the intrinsic efficacy $\alpha$ of radioligand $\mathrm{L}$, that is the ratio between affinities (and therefore selectivity) shown by L towards RG and $\mathrm{R}$; (c) the intrinsic efficacy $\beta$ of the modulator $\mathrm{A}$, that is the ratio between affinities (and therefore selectivity) shown by A towards RG and R; (d) the binding cooperativity $\gamma$ between A molecules and $\mathrm{G}$, that is the ratio between affinities shown by A towards GRA and RA; (d) the binding cooperativity $\delta$ between A, L and G, that is the ratio of affinities shown by A towards GRL and RL. These parameters may affect, as already mentioned, the height of the curves, while allowing them to retain their global shapes. The $\alpha$ parameter only depends on the receptor $(\mathrm{R})$ and radioligand $(\mathrm{L})$ type. More in 
detail, $\alpha$ is lower than 1 for agonists, higher than 1 for antagonists or inverse agonists, and equal to 1 for neutral antagonists. When $\alpha=1$, a change in the $G / K_{5}$ ratio does not affect the curve. However, it should be noted that if $\alpha$ is higher than 1 (an antagonist radioligand) and, for instance, the allosteric modulator belongs to the enhancer type (Fig. 5), when the $\mathrm{G} / \mathrm{K}_{5}$ ratio increases, then the receptor occupancy in the absence of modulator decreases. Thus, the basal value of total binding decreases, so, when reporting the enhancer effect as a percentage with respect to the basal value of receptor occupancy, as usually done in the literature, we should observe an increase of binding percentage with respect to basal value (Fig. 5).

Such considerations highlight the importance of exactly retaining the same operative conditions used in performing binding assays, when the allosteric modulator effects are being measured. For instance, it may be critical to keep the same $\mathrm{G} / \mathrm{K}_{5}$ ratio, which can be affected in a different way by buffers containing or not the magnesium ions. In fact, it is well known that magnesium promotes the interaction between receptor and Gprotein (Hulme, 1990), thus apparently decreasing the $\mathrm{K}_{5}$ value. A similar consideration may be done for agonist radioligands, the $\alpha$ parameter of which is lower than 1 . Of course, some effects on the basal receptor occupancy may also be brought by changes in radioligand concentration, for instance at lower radioligand concentrations the percent positive effect will be higher than at higher radioligand concentrations.

It should be observed that $\alpha$ depends on the radioligand-receptor pair, while the $\beta$ and $\gamma$ parameters depend on the modulator and receptor nature, and $\delta$ depends on the nature of the radioligand used. If an ECAM modulator shows a particular effect with a given radioligand, for instance an enhancer effect, the same modulator, in the presence of the same receptor and a different radioligand, may show changes in its effect becoming, for 
example, competitive. As a consequence, it is always suitable for a given receptor to refer to its physiological ligand in order to analyze behavior and affinity of a modulator towards such a receptor, and to measure its thermodynamic constants as well.

As a conclusive comment, it is worth to mention the possibility of facing the case where the system comprises two distinct receptor microdomains, for example a receptor pool completely uncoupled to G-protein and another receptor pool completely coupled to Gprotein. In this case, more complex behaviors are observed. An equation capable of globally describing such behaviors could be obtained by the sum of the individual equations for each microdomain. In particular, the sum of equation (Eq. 28) with equation (Eq. 29) of Appendix will describe this specific case. The curve generated in these cases would be the sum of the different curves referring to each microdomain as well.

$\underline{\text { Saturation-like binding assay simulations }}$

Saturation-like binding experiments are carried out on systems consisting of the receptor or the $\mathrm{G}$ protein-receptor complex (at a constant concentration), the ligand $\mathrm{A}$ (at a constant concentration), and the radioligand L, the concentration of which is changed in different experimental steps. Both the model and the equation accounting for the behavior of the system components are analogous to the ones described in the case of displacement experiments, but, in the case of saturation experiments, the radioligand concentration is the independent variable.

The parameters and other quantities used for simulations are listed below: a hypothetical receptor $(10 \mathrm{pM})$, and radioligand $\left(\mathrm{K}_{\mathrm{d}} \equiv \mathrm{K}_{1}=1 \mathrm{nM}\right.$, specific activity $=120$ $\mathrm{Ci} / \mathrm{mmol}$ ), with an assay volume of $0.4 \mathrm{~mL}, \mathrm{C}=2.22 \cdot 10^{12}$, and a concentration ranging 
from 0.1 to $10 \mathrm{nM}$, in the absence, control, and in the presence of an allosteric modulator $\left(\mathrm{K}_{2}=10^{-5}, \mathrm{~K}_{3}=10^{-7}, \mathrm{~K}_{4}=10^{-7} \mathrm{M}\right)$ at a concentration needed for the enhancer effect $(1 \mu \mathrm{M})$, and at a concentration required for the competition effect $(50 \mu \mathrm{M})$ (see Fig. 6). It should be noted that the curve, at the concentration required for the enhancer effect, is steeper, showing an increase in the apparent $\mathrm{K}_{\mathrm{d}}$ of the radioligand, with respect to the one (broader) corresponding at the concentration required for the competition effect, with an apparent decrease in the $K_{d}$ value. However, it should be pointed out that in the absence of modulator (both at competitive and enhancer concentrations) the $\mathrm{B}_{\max }$ values, which represent the total receptor amount obtained by extrapolation of the curve, does not change. Changes in $\mathrm{B}_{\max }$ may be found in a system where a G-protein depletion is observed, or in the case where more microdomains are present, but these cases were not analyzed here.

\section{$\underline{\text { Dissociation kinetic binding assay simulations }}$}

In a dissociation experiment, the receptor is kept under conditions of equilibrium with the radioligand. The dissociation is then induced by means of an excess of a competitive inhibitor, which can be the cold analogue of the same radioligand, at a concentration 10,000 times higher than the concentration of the radioligand itself. At this time, all the receptor molecules not complexed with radioligand will be captured at once by the cold ligand. On the other hand, the molecules already bound to radioligand, from which they dissociate by virtue of the equilibrium between free and complexed species, will tend to bind the cold ligand, because of its strongly higher concentration. The dissociation is monitored as a function of the time. The dissociation rate $\left(\mathrm{k}_{-1}\right.$, Fig. $\left.3 \mathrm{~A}\right)$ is exclusively related to the dissociation constant of radioligand from receptor. When a modulator is 
present in the system together with the cold inhibitor which causes dissociation, a decrease in dissociation rate of the radioligand will always be observed, if the formation rate of the RLA complex is not negligible, with respect to the dissociation rate of the RL complex. As a practical rule, it can be stated that when the concentration of $\mathrm{A}$ is higher than $\mathrm{k}_{-4} / \mathrm{k}_{4}\left(=\mathrm{K}_{4}\right)$, then the dissociation rate decreases. Such a system is schematically represented in Fig. 3A and its behavior is described by the set of ordinary differential equations (ODEs) and non-linear algebraic equations (NAEs) reported in Appendix.

A decreasing dissociation rate also occurs for those compounds that appear to behave as negative allosteric modulators in displacement-like binding assay simulations (Figs. 4D to 4I). A simulation, that applies the ECAM model to the system described below, shows this effect (Fig. 7). The system consists of a hypothetical receptor (10 pM), and a radioligand (concentration: $1 \mathrm{nM} ; \mathrm{K}_{\mathrm{d}} \equiv \mathrm{K}_{1}=1 \mathrm{nM}$ coming from $\mathrm{k}_{1}=10^{6} \mathrm{M}^{-1} \mathrm{~s}^{-1}$ and $\mathrm{k}_{-1}$ $=10^{-3} \mathrm{~s}^{-1}$, specific activity $=120 \mathrm{Ci} / \mathrm{mmol}$ ). The radioligand binding experiment is carried out under dissociation kinetic conditions obtained by means of an excess of cold inhibitor (with the same kinetic parameters of radioligand, at a 10,000 times higher concentration), with an assay volume of $0.4 \mathrm{~mL}, \mathrm{C}=2.22 \cdot 10^{12}$, in the absence and in the presence of an ECAM modulator at a concentration higher than $\mathrm{K}_{4}=\mathrm{k}_{-4} / \mathrm{k}_{4}$, exactly at a concentration of modulator $=0.1 \mathrm{nM}$ and $\mathrm{K}_{4}=10^{6} \mathrm{M}^{-1} \mathrm{~s}^{-1} ; \mathrm{k}_{-4}=10^{-4} \mathrm{~s}^{-1}$.

In some reports from the literature, the enhancer potency of a compound has been associated to a capability of decreasing the dissociation rate (Tranberg et al., 2002). On the basis of the results shown above, we observe that a compound, showing a negative effect in equilibrium experiments, may also decrease the dissociation rate of the radioligand. It suggests that a decrease in dissociation rate can not be diagnostic of enhancer ligand properties. 


\section{$\underline{\text { Association kinetic binding assay simulations }}$}

In an association experiment, the receptor is kept under equilibrium conditions with the radioligand and with the allosteric modulator. Binding is monitored as a function of the time. Such a system is schematically represented in Fig. 8 and its behavior is described by the set of ordinary differential equations (ODEs) and non-linear algebraic equations (NAEs) reported in Appendix. A number of quite complex behaviors may be analyzed by this approach. Fig. 8 illustrates some of them obtained by using the parameters listed in Table 2.

It should be noted that the control curve always shows an increasing hyperbolic-like trend. In the presence of a modulator, the shape of this curve may dramatically change, not only due to changes in the kinetic constants of modulator and radioligand, but also due to changes in the concentrations of the species involved in the system (see Table 2). Typical curve trends that can be observed in the presence of a modulator (Fig. 8) are briefly described below: curve with a fast increasing trend with plateau higher than control (8A); curve with a slow increasing trend with a plateau higher than control (8B); curve with a slow increasing trend with a plateau lower than control (8C); curve showing a trend inversion with both maximum and plateau lower than control (8D); curve showing a trend inversion with a maximum higher and a plateau lower than control (8E); curve showing a more complex shape due to the contribution of different trends $(8 \mathrm{~F})$; curve with a slow increasing trend with a plateau equal to control $(8 \mathrm{G})$; and curve with a complex increasing trend, showing an initial hyperbolic-like portion followed by a second hyperbolic-like portion increasing very slowly and closely approaching a straight line $(8 \mathrm{H})$. 
Analyzing each single curve and the experimental conditions by which they were generated, some considerations may be inferred. They are listed below. The case represented in Fig. 8A corresponds to conditions where the sum of formation rates and the produced amount of the RL and RLA complexes are higher than formation rates and total produced amounts of RL in the control, respectively. The case represented in Fig. $8 \mathrm{~B}$ corresponds to slower formation rate of the same complexes, with total produced amount of them higher than control. The case represented in Fig. 8C corresponds to formation rates and produced amounts of the same complexes both lower than control. The case represented in Fig. $8 \mathrm{C}$ corresponds to formation rates and produced amounts of the same complexes both lower than control. When the radioligand rapidly binds the receptor, but the formation of the $\mathrm{RA}$ e $\mathrm{RA}_{2}$ inhibitor species is slow, an inversion of the curve trend is observed, which presents a maximum lower than control (Fig. 8D). The case where the formation rate of the RLA complex is slow, the equilibrium amounts of RA and $\mathrm{RA}_{2}$ are higher than the amounts of RL and RLA, and the formation of the RLA complex is faster than the formation of the unlabelled RA e RA 2 species is represented in Fig. 8E. The curve presents a maximum higher than control. The case represented in Fig. 8F also shows an inversion of the curve trend, due to the slow formation of the RLA complex. The particular shape of the curve, represented in Fig. $8 \mathrm{H}$, is due to a very slow formation of the RLA complex.

The typical trends of experimental curves shown in Fig. 8 appear to refer to quite complex behaviors of the biological system under analysis. Nevertheless, at a more detailed analysis, they turn out to supply an useful exemplification of possible experimental conditions that helps in accurately defining the profile of a modulator.

They can be particularly useful when, in designing new molecules, a given 
pharmacological effect (such as enhancer or competitive) is desirable to be retained over a certain range of time, for a given receptor present at a given concentration, for a given radioligand (the labeled form of the physiological ligand) and for a given range of possible therapeutic concentrations.

As an example, the most suited kinetic behavior for optimization of an ECAM modulator, as well as for choosing analogues, when the modulator is desired to constantly act as an enhancer over the time and at various concentrations, would be the fast increasing hyperbolic-like trend, with a plateau higher than control, as illustrated in Fig. 8A.

$\underline{\text { Radioligand binding assay of PD81723 at the adenosine } \mathrm{A}_{1} \text { receptor and results of the }}$ fitting with the ECAM model

In order to assess the ability of the ECAM model to fit experimental data, both thermodynamic and kinetic affinity parameters of PD81723 against the radioligand $\left[{ }^{3} \mathrm{H}\right] \mathrm{CCPA}$ at the rat brain cortex adenosine $\mathrm{A}_{1}$ receptor were determined. Despite both thermodynamic and kinetic data about the binding of PD81723 at the adenosine $A_{1}$ receptor can be found in the literature (as, for example, reviewed by Christopoulos and Kenakin, 2002), the authors preferred to experimentally perform the radioligand binding assay of PD81723 at that receptor in order to fit real experimental data with the ECAM model, instead of data taken from the literature. For the same reason, thermodynamic and kinetic data for $\left[{ }^{3} \mathrm{H}\right] \mathrm{CCPA}$ at the adenosine $\mathrm{A}_{1}$ receptor were experimentally determined as well.

Crude membranes were prepared according to the following protocol. Brain cortices of male Wistar rats were homogenated in 10 volumes of ice-cooled buffer containing 0,32 
M sucrose, $20 \mathrm{mM}$ Tris $\mathrm{HCl}, \mathrm{pH} 7.4$, with 30 strokes of a Dounce homogenizer. The homogenate was centrifuged at $1,000 \mathrm{~g}$ for $10 \mathrm{~min}$ to remove the nuclear fraction, ad the resulting supernatant was centrifuged at $30,000 \mathrm{~g}$ for $30 \mathrm{~min}$. The pellet was resuspended with 10 strokes of a Dounce homogenizer in 10 volumes of ice-cooled 5 $\mathrm{mM}$ Tris $\mathrm{HCl}$ buffer, $\mathrm{pH} 7.4$, for 30 min. After further homogenation with Dounce, the resulting membranes were preincubated for $30 \mathrm{~min}$ at $37^{\circ} \mathrm{C}$ with $2 \mathrm{U} / \mathrm{ml}$ adenosine deaminase to remove the endogenous adenosine. The membrane suspension was then centrifuged at $48,000 \mathrm{~g}$ for $30 \mathrm{~min}$; the resulting pellet was resuspended in 10 volumes of $50 \mathrm{mM}$ Tris $\mathrm{HCl}$ buffer, $\mathrm{pH} 7.4$ and stored at $-80^{\circ} \mathrm{C}$ until binding assay.

A saturation experiment was performed to determine the dissociation constant $\left(\mathrm{K}_{\mathrm{d}}\right)$ of the radioligand $\left[{ }^{3} \mathrm{H}\right] \mathrm{CCPA}$. This constant corresponds to $\mathrm{K}_{1}$ of the ECAM model. Membranes (40 $\mu \mathrm{g}$ of protein) were incubated at $25^{\circ} \mathrm{C}$ for $180 \mathrm{~min}$ with increasing concentrations of $\left[{ }^{3} \mathrm{H}\right] \mathrm{CCPA}$ from $0.1 \mathrm{nM}$ up to $10 \mathrm{nM}$, in a final volume of $0.4 \mathrm{ml}$ of $50 \mathrm{mM}$ Tris $\mathrm{HCl}$ buffer, $\mathrm{pH}$ 7.4. The aspecific binding was measured in the presence of $10 \mu \mathrm{M}$ DPCPX. Binding reactions were stopped by dilution with ice-cooled $50 \mathrm{mM}$ Tris $\mathrm{HCl}$ buffer, $\mathrm{pH}$ 7.2. Samples were then filtrered through glass fiber filters (Whatman GF/C) by using a Brandel Cell Harvester. Filters were washed three times with 2-3 ml of the same buffer. The filter bound radioactivity was measured in a liquid scintillation counter (1600 TR Packard) after the addition of $4 \mathrm{ml}$ of scintillation liquid (EmulsifierSafe, Packard). The analysis of results by means of the formula $S=S_{\text {Max }}[L]\left(K_{d}+[L]\right)$, wherein $\mathrm{S}$ is the specific signal of $[\mathrm{RL}]$ complexes and $\mathrm{S}_{\mathrm{Max}}$ is the maximum specific signal of [RL] complexes, led to a $\mathrm{K}_{\mathrm{d}}$ value of $0.8 \mathrm{nM}$.

In kinetic experiments, the association at $25^{\circ} \mathrm{C}$ was started by the addition of membranes to $1 \mathrm{nM}\left[{ }^{3} \mathrm{H}\right] \mathrm{CCPA}$ in the presence or the absence of test compound $(10 \mu \mathrm{M}$ 
PD81723), in quadruplicate, at proper time intervals. The time progression of the association of total binding was measured by rapid filtration through glass fiber filters (Whatman GF/B), washing three times with $2 \mathrm{ml}$ of ice-cooled buffer. Samples were handled as described above.

In kinetic dissociation studies with adenosine $A_{1}$ receptor, a single concentration of $\left[{ }^{3} \mathrm{H}\right] \mathrm{CCPA}(1 \mathrm{nM})$ was used. Membranes $\left(40 \mu \mathrm{g}\right.$ of protein) were incubated at $25^{\circ} \mathrm{C}$ for 180 min. Dissociation was started by the addition of $10 \mu \mathrm{M}$ CCPA in the presence or the absence of test compound (10 $\mu \mathrm{M}$ PD81723), in quadruplicate, at proper time intervals. The time progression of the dissociation of total binding was measured by rapid filtration through glass fiber filters (Whatman GF/B), washing three times with 2 $\mathrm{ml}$ of ice-cooled buffer. Samples were handled as described above.

The analysis of association and dissociation experiments carried out in the absence of test compound (10 $\mu \mathrm{M}$ PD81723) allowed calculating the kinetic constants $\mathrm{k}_{1}$ and $\mathrm{k}_{-1}$ of $\left[{ }^{3} \mathrm{H}\right] \mathrm{CCPA}$, by non linear regression of the experimental data collected, by means of the ECAM model, and setting 0 (zero) the absent species. Values for these kinetic constants were $\mathrm{k}_{1}=1.16 \times 10^{6} \mathrm{M}^{-1} \mathrm{~s}^{-1}$ and $\mathrm{k}_{-1}=9.70 \times 10^{-4} \mathrm{M}^{-1} \mathrm{~s}^{-1}$.

For displacement experiments, membranes (40 $\mu \mathrm{g}$ of protein) were incubated at $25^{\circ} \mathrm{C}$ for 60 min with $\left[{ }^{3} \mathrm{H}\right] \mathrm{CCPA}(1 \mathrm{nM})$ and with increasing concentrations of test compound in a final volume of $0.4 \mathrm{ml}$ of $50 \mathrm{mM}$ Tris $\mathrm{HCl}$ buffer, $\mathrm{pH}$ 7.4. The aspecific binding was measured in the presence of $10 \mu \mathrm{M}$ CCPA. Binding reactions were stopped by dilution with ice-cooled $50 \mathrm{mM}$ Tris $\mathrm{HCl}$ buffer, $\mathrm{pH}$ 7.4. Samples were then filtered through glass fiber filters (Whatman GF/C) by using a Brandel Cell Harvester. Filters were washed three times with $2-3 \mathrm{ml}$ of the same buffer. The filter bound radioactivity was measured in a liquid scintillation counter (1600 TR Packard) after the addition of 4 
$\mathrm{ml}$ of scintillation liquid (Emulsifier-Safe, Packard).

The analysis of displacement experiments, by non linear regression of the experimental data collected, by means of the ECAM model represented by Eq. 28 (see Appendix), along with the analysis of the association and dissociation kinetic experiments carried out in the absence of test compound (10 $\mu \mathrm{M}$ PD81723) by non linear regression of the experimental data collected, by means of the ECAM model, defined by the ODE/NAE system reported in the Appendix, allowed the calculation of both kinetic parameters for the binding of PD81723 at the adenosine $\mathrm{A}_{1}$ receptor (see Table 3) and its association thermodynamic parameters (see Table 4).

Results of both kinetic and displacement experiments are illustrated in Figs. 9, 10, and 11.

Comparison between the ECAM model and the model proposed by Christopoulos and $\underline{\text { Kenakin }}$

For the validation of the model presented here (ECAM model), a special attention was paid to a comparison between the ECAM model itself (Fig. 3B) and the CK model (Christopoulos and Kenakin, 2002, Fig. 1D), since the latter separately takes into account the orthosteric and allosteric interactions at the orthosteric and allosteric sites, respectively.

The differences and analogies which emerged from this comparison are summarized in Table 5. Briefly, on the one hand, the CK model takes into account the two different sites ( $a$ and $o$ ) for the binding of the allosteric modulator A, while the ECAM model does not. Moreover, the more complex CK model involves seven equilibria and requires five parameters $\left(\mathrm{K}_{\mathrm{A}}, \mathrm{K}_{\mathrm{B} 1}, \mathrm{~K}_{\mathrm{B} 2}, \alpha\right.$ and $\left.\beta\right)$ in the relevant equation (Fig. 12), while the 
ECAM model only involves four equilibria and requires four parameters $\left(\mathrm{K}_{1}, \mathrm{~K}_{2}, \mathrm{~K}_{3}\right.$, and $\mathrm{K}_{4}$ ) in the relavant equation (see Eq. 28 in Appendix). In particular, the ECAM model does not allow the binding of a second molecule of allosteric modulator A to the receptor $\mathrm{R}$ when $\mathrm{R}$ is already bound to a first molecule of $\mathrm{A}$ at the allosteric site and the binding of the ligand $\mathrm{L}$ at the orthosteric site when $\mathrm{R}$ is already bound to a first molecule of A at the allosteric site.

Despite the ECAM model does not consider these equilibria, it is able to fit bell-shaped curves as well as very steep curves, at least for the cases analysed in this paper (Figs. 4B and 4E). These findings enabled the authors to speculate about relative positions, with respect to each other, occupied within the receptor by the orthosteric and the allosteric sites. The locations of these binding sites are in turn related to the path the ligand molecules have to follow to reach their binding sites. Indeed, it is reasonable to consider that, when the allosteric site is already occupied, it is not possible for another ligand (either A, or L) to reach the orthosteric site. This could be due to the fact that the allosteric site is located along the path followed by a ligand to reach the orthosteric site itself and the occupancy of the allosteric site by A hinders this path.

These hypotheses are also in agreement with concepts found in the scientific literature (for example, see Wang and Duan, 2009), according to which the active sites which bind endogenous ligands are supposed to be located within the transmembrane helices, as well known for rhodopsin-like GPCRs. Also, there are evidences that a ligand could penetrate into the receptor's active site located within the transmembrane helices by previously binding other sites at a more external level with respect to the membrane, at the border with its extracellular side. A simple summarization is illustrated in Fig. 13. 


\section{Conclusions}

In this work, the development of a new model (referred to as ECAM model) is described together with its use to simulate a number of experiments, such as displacement-like, saturation-like, dissociation kinetic, and association kinetic experiments.

Simulations pointed out that the ECAM model could provide the starting point for the design of allosteric modulators and their optimization, on the basis of the proposed interaction mechanism of the modulator at an allosteric site. It allows extracting from experimental data accurate values for the affinity of a modulator towards the receptor, in terms of thermodynamic constants instead of the commonly used scores or percent effects (that are less reproducible). The binding affinity of the modulator, given as a thermodynamic constant, is a parameter that medicinal chemists can easily exploit during the optimization of classes of designed compounds.

Simulations of the ECAM model carried out for compounds with unusual behavior gave results comparable with simulations of the CK model, although the ECAM model shows a lower complexity, in that it requires a lower number of equilibria and a lower number of parameters and thermodynamic constants. According to these findings, the ECAM model could be considered as a particular case of the CK model, enabling an easier interpretation of results coming from radioligand binding assays for compounds that behave like PD81723.

The results obtained also allowed the authors to hypothesize the path the ligand molecules have to follow to reach their binding sites, the allosteric site being located along the path followed by a ligand to reach the orthosteric one.

Finally, it should be pointed out that, being the allosteric sites less conserved, even 
among subtypes of the same receptor, with respect to the orthosteric site, a quite high probability that an ECAM modulator shows increased selectivity towards a given receptor subtype is expected. 


\section{Acknowledgments}

The Authors are grateful to International Centre for studies and research in Biomedicine (ICB), Luxembourg and to International Society for Drug Development (ISDD), Milano (Italy), for the financial support granted to research team.

\section{References}

Bjarnadóttir, T. K., Gloriam, D. E., Hellstrand, S. H., Kristiansson, H., Fredriksson, R., Schiöth H. B., 2006. Comprehensive repertoire and phylogenetic analysis of the $\mathrm{G}$ protein-coupled receptors in human and mouse. Genomics 88, 263-273, doi: 10.1016/j.ygeno.2006.04.001

Bruns, R. F. and Fergus J. H., 1990. Allosteric enhancement of adenosine A1 receptor binding and function by 2-amino-3-benzoylthiophenes. Mol. Pharmacol. 38, 939-949 Christopoulos, A. and Kenakin, T., 2002. G protein-coupled receptor allosterism and complexing. Pharm. Rev. 54, 323-374

Eherlert, F. J., 1988. Estimation of the affinities of allosteric ligands using radioligand binding and pharmacological null methods. Mol. Pharmacol. 33, 187-94

Fredriksson, R., Lagerström, M. C., Lundin, L.-G., Schiöth H. B., 2003. The G-proteincoupled receptors in the human genome form five main families: phylogenetic analysis, paralogon groups, and fingerprints. Mol. Pharmacol. 63, 1256-1272

Goryanin, I., Hodgman, T. C., Selkov, E., 1999. Mathematical simulation and analysis of cellular metabolism and regulation. Bioinformatics 15, 749-758

Hall, D. A., 2000. Modeling the functional effects of allosteric modulators at pharmacological receptors: an extension of the two-state model of receptor activation. 
Mol. Pharmacol. 58:1412-1423

Hoare, S. R. J. and Strange, P. G., 1996. Regulation of D2 dopamine receptors by amiloride and amiloride analogs. Mol. Pharmacol. 50, 1295-1308

Hulme, E. C., 1990. Receptor biochemistry, A Practical Approach., IRL Press/Oxford. University Press, New York Jaakola, V.-P., Griffith, M. T., Hanson, M. A., Cherezov, V., Chien, E. Y. T., Lane, J. R., IJzerman, A. P., Stevens, R. C., 2008. The 2.6 angstrom crystal structure of a human A2A adenosine receptor bound to an antagonist. Science, 322, 1211-1217., doi:

10.1126/science. 1164772

Rasmussen, S. G. F., Choi, H.-J., Rosenbaum, D. M., Kobilka, T. S., Thian, F. S., Edwards, P. C., Burghammer, M., Ratnala, V. R. P., Sanishyili, R., Fischetti, R. R., Schertler, G. F. X., Weis, W. I., Kobilka, B. K., 2007. Crystal structure of the human beta(2) adrenergic G-protein-coupled receptor. Nature 450, 383-387, doi:

10.1038 /nature06325

Samana, P., Cotecchia, S., Costa, T., Lefkowitz, R. J., 1993. A mutation-induced activated state of the $\beta_{2}$-adrenergic receptor: extending the ternary complex model. J. Biol. Chem. 268, 4625-36

Schiöth H. B., Fredriksson, R., 2005. The GRAFS classification system of G-protein coupled receptors in comparative perspective. Gen. Comp. Endocrinol. 142, 94-101, doi:10.1016/j.ygcen.2004.12.018.

Tranberg, C. E., Zickgraf, A., Giunta, B. N., Luetjens, H., Figler, H., Murphree, L. J., Falke, R., Fleischer, H., Linden, J., Scammells, P. J., Olsson, R. A., 2002. 2-Amino-3aroyl-4,5-alkylthiophenes: agonist allosteric enhancers at human A1 adenosine receptors. J. Med. Chem. 45, 382-389., doi: 10.1021/jm010081p. 
Wang, D., Duan, Y., 2009. Ligand entry and exit pathways in the $\beta_{2}$-adrenergic receptor. J. Mol. Biol. 392, 1102-1115 


\section{Legends for figures:}

Fig. 1 Schematic representation of Allosteric ternary complex model (1A), Extended ternary complex model (1B), Allosteric two state model (1C), and CK model for the concomitant orthosteric and allosteric interaction (1D). Parameters characterizing these models are defined in the respective references (Eherlet, 1988; Samana et al., 1993; Hall, 2000; Christopoulos and Kenakin, 2002)

Fig. 2 The Enhancer and Competitive Allosteric Modulator (ECAM) model. The radioligand (L) is found in the bound and unbound forms with respect to the orthosteric site of the receptor $(\mathrm{R})$. The allosteric and competitive modulator (A) may bind the orthosteric site, as well as to an allosteric site when the orthosteric one is already occupied by L or another molecule of A (2B). Analogous equilibria may be established when $\mathrm{R}$ is completely bound to G-protein $(\mathrm{G})$ to form the GR complex (2C). The B and $\mathrm{C}$ models are in equilibrium, with regard to the binding of $\mathrm{R}$ to $\mathrm{G}$. The whole scheme is represented in Fig. 2A. The relevant thermodynamic equilibrium constants are drawn over the arrows.

Fig. 3 The kinetic scheme of the ECAM model, in the presence of an allosteric modulator (A) and a radioligand (L) (3B), and also in the presence of a competitive inhibitor (I) (3A), both I and L being modulated by A. Kinetic constants relative to each reaction are drawn over the arrows.

Fig. 4 Simulations based on the ECAM equation of radioligand binding experiments 
under competition-like conditions with the simulation parameters reported in Table 1. In plots 4A, 4b, AND 4C, the positive enhancer effects occur, while in plots 4D to 4F the displacement effects are higher (4D and $4 \mathrm{E}$ ) or comparable (4F) to the positive enhancer effects. The plots $4 \mathrm{G}$ to $4 \mathrm{I}$ show, other than displacement effects, a radioligand displacement which does not reach the aspecific levels $(4 \mathrm{G})$, which gives rise to a smooth curve $(4 \mathrm{H})$, or presents a biphasic trend (4I).

Fig. 5 Effect of basal occupancy on the enhancer effect of a modulator.

Fig. 6 Simulation based on the ECAM equation of radioligand binding experiments under saturation-like conditions using a hypothetical receptor $(10 \mathrm{pM})$, and radioligand $\left(1 \mathrm{nM}, \mathrm{K}_{\mathrm{d}} \equiv \mathrm{K}_{1}=1 \mathrm{nM}\right.$, specific activity $\left.=120 \mathrm{Ci} / \mathrm{mmol}\right)$, with an assay volume of 0.4 $\mathrm{mL}, \mathrm{C}=2.22 \cdot 10^{12}$, and a concentration ranging from 0.1 to $10 \mathrm{nM}$, in the absence, control, and in the presence of allosteric modulator $\left(\mathrm{K}_{2}=10^{-5}, \mathrm{~K}_{3}=10^{-7}, \mathrm{~K}_{4}=10^{-7} \mathrm{M}\right)$, at a concentration needed for enhancer effect $(1 \mu \mathrm{M})$, and at a concentration required for competition effect $(50 \mu \mathrm{M})$.

Fig. 7 Simulation of the ECAM model for a hypothetical receptor (10 pM), and radioligand $\left(1 \mathrm{nM}, \mathrm{K}_{\mathrm{d}} \equiv \mathrm{K}_{1}=1 \mathrm{nM}\right.$ relatives $\mathrm{k}_{1} 10^{6} \mathrm{M}^{-1} \mathrm{~s}^{-1} \mathrm{k}_{-1} 10^{-3} \mathrm{~s}^{-1}$, specific activity $=$ $120 \mathrm{Ci} / \mathrm{mmol}$ ) in radioligand binding experiment under dissociation kinetic conditions obtained by means of an excess of cold inhibitor (with the same kinetic parameters of radioligand, at a 10,000 times higher concentration), with an assay volume of $0.4 \mathrm{~mL}, \mathrm{C}$ $=2.22 \cdot 10^{12}$, in the absence and in the presence of an ECAM modulator at a concentration higher than $\mathrm{K}_{4}=\mathrm{k}_{-} / \mathrm{k}_{4}$, exactly at a modulator concentration of $0.1 \mathrm{nM}$; 
$\mathrm{K}_{4}=10^{6} \mathrm{M}^{-1} \mathrm{~s}^{-1}$, and $\mathrm{k}_{-4}=10^{-4} \mathrm{~s}^{-1}$.

Fig. 8 The main kinds of curves that can be observed in the presence of a modulator are substantially the ones summarized below: curve with a fast increasing trend with plateau higher than control (8A), curve with a slow increasing trend with plateau higher than control (8B), curve with a slow increasing trend with plateau lower than control (8C), curve showing an overshoot with both maximum and plateau lower than control (8D), curve showing an overshoot with maximum higher and plateau lower than control (8E), curve showing an overshoot with maximum lower than control, followed by an increasing hyperbolic-like region reaching a plateau lower than control $(8 \mathrm{~F})$, curve with a slow increasing trend with plateau equal to control $(8 \mathrm{G})$, and increasing biphasic curve, showing an initial hyperbolic-like region followed by a slow hyperbolic-like region which looks almost like a straight line $(8 \mathrm{H})$.

Fig. 9 Association of $\left[{ }^{3} \mathrm{H}\right] \mathrm{CCPA}$ at the rat brain cortex adenosine $\mathrm{A}_{1}$ receptor, in the presence and the absence of PD81723

Fig. 10 Dissociation of $\left[{ }^{3} \mathrm{H}\right] \mathrm{CCPA}$ at the rat brain cortex adenosine $\mathrm{A}_{1}$ receptor, in the presence and the absence of PD81723

Fig. 11 Effect of changes in PD81723 concentrations on the $\left[{ }^{3} \mathrm{H}\right] \mathrm{CCPA}$ binding to the rat brain cortex adenosine $A_{1}$ receptor

Fig. 12 Equation derived from the CK model, where $\rho_{\mathrm{A}}$ is the revealed signal consisting 
of the radioactivity associated with the receptor, $\mathrm{K}_{\mathrm{A}}, \mathrm{K}_{\mathrm{B} 1}$, and $\mathrm{K}_{\mathrm{B} 2}$ are the equilibrium dissociation constants, $\alpha$ and $\beta$ are the cooperativity factors.

Fig. 13 Representation of a GPCR with orthosteric binding site located into the helix bundle of the receptor and an allosteric site located above the orthosteric site on R. The penetration way of ligands (both competitive and allosteric) into the receptor is also represented. 
Table 1: Parameters for competition-like experiments of the ECAM equation simulations reported in Fig. 4.

\begin{tabular}{|c|c|c|c|}
\hline \multirow{2}{*}{$\begin{array}{c}\text { Simulation } \\
\text { summarized } \\
\text { in Fig. } 4\end{array}$} & \multicolumn{3}{|c|}{ Thermodynamic constants (M) } \\
\hline & $\mathrm{K}_{2}$ & $\mathrm{~K}_{3}$ & $\mathrm{~K}_{4}$ \\
\hline $\mathrm{A}$ & $10^{-5}$ & $10^{-5}$ & $10^{-9}$ \\
\hline B & $10^{-5}$ & $10^{-7}$ & $10^{-7}$ \\
\hline $\mathrm{C}$ & $10^{-5}$ & $10^{-7}$ & $10^{-9}$ \\
\hline $\mathrm{D}$ & $10^{-9}$ & $10^{-3}$ & $10^{-3}$ \\
\hline $\mathrm{E}$ & $10^{-7}$ & $10^{-9}$ & $10^{-7}$ \\
\hline $\mathrm{F}$ & $10^{-9}$ & $10^{-1}$ & $10^{-9}$ \\
\hline $\mathrm{G}$ & $10^{-9}$ & $10^{-2}$ & $5 \cdot 10^{-9}$ \\
\hline $\mathrm{H}$ & $6 \cdot 10^{-9}$ & $5 \cdot 10^{-7}$ & $2.5 \cdot 10^{-8}$ \\
\hline $\mathrm{I}$ & $10^{-7}$ & $10^{-4}$ & $2.5 \cdot 10^{-7}$ \\
\hline \multicolumn{4}{|c|}{$\begin{array}{l}\mathrm{K}_{1} 1 \mathrm{nM} \text {, receptor } 10 \mathrm{pM} \text {, specific activity } 120 \mathrm{Ci} / \mathrm{mmol} \text {, } \\
\text { assay volume } 0.4 \mathrm{~mL}, \mathrm{C}=2.22 \cdot 10^{12} \text {, allosteric modulator } \\
\text { concentrations are in the range } 10^{-12} \text { to } 10^{-3} \mathrm{M}\end{array}$} \\
\hline
\end{tabular}


Table 2: Parameters for the association kinetic experiment simulations reported in Fig.

8.

\begin{tabular}{|c|c|c|c|c|c|c|c|}
\hline Simulation & Conc. & Conc. & \multicolumn{5}{|c|}{ Kinetic costants } \\
\hline $\begin{array}{c}\text { summarized } \\
\text { in Fig. } 8\end{array}$ & $\begin{array}{c}\mathrm{A} \\
(\mathrm{nM})\end{array}$ & $\begin{array}{c}\mathrm{Rt} \\
(\mathrm{pM})\end{array}$ & $\mathrm{k}_{-1}, \mathrm{~s}^{-1}$ & $\mathrm{k}_{2}, \mathrm{M}^{-1} \mathrm{~s}^{-1}$ & $\mathrm{k}_{-2}, \mathrm{~s}^{-1}$ & $\mathrm{k}_{4}, \mathrm{M}^{-1} \mathrm{~s}^{-1}$ & $\mathrm{k}_{-4}, \mathrm{~s}^{-1}$ \\
\hline $8 \mathrm{~A}$ & 1 & 10 & $10^{-3}$ & $10^{5}$ & $10^{-3}$ & $10^{5}$ & $1 \mathrm{~s}^{-1}$ \\
\hline $8 B$ & 1 & 10 & $10^{-3}$ & $10^{7}$ & $10^{-1}$ & $10^{5}$ & $10^{-4}$ \\
\hline $8 \mathrm{C}$ & 1 & 10 & $10^{-3}$ & $10^{5}$ & 1 & $10^{5}$ & $10^{-4}$ \\
\hline $8 \mathrm{D}$ & 1 & 10 & $10^{-3}$ & $10^{5}$ & $10^{-4}$ & $10^{7}$ & 1 \\
\hline $8 \mathrm{E}$ & 5 & 10 & $10^{-3}$ & $10^{5}$ & $10^{-5}$ & $10^{7}$ & $10^{-2}$ \\
\hline $8 \mathrm{~F}$ & 5 & 100 & $10^{-2}$ & $10^{6}$ & $10^{-3}$ & $10^{5}$ & $10^{-4}$ \\
\hline $8 \mathrm{G}$ & 1 & 10 & $10^{-3}$ & $10^{7}$ & $10^{-1}$ & $10^{5}$ & $10^{-3}$ \\
\hline $8 \mathrm{H}$ & 10 & 10 & $10^{-3}$ & $10^{6}$ & $10^{-3}$ & $10^{5}$ & $10^{-4}$ \\
\hline
\end{tabular}

Concentration of radioligand $\mathrm{L}$ is $1 \mathrm{nM}, \mathrm{k}_{1}=10^{6} \mathrm{M}^{-1} \mathrm{~s}^{-1}, \mathrm{k}_{3}=10^{5} \mathrm{M}^{-1} \mathrm{~s}^{-1}, \mathrm{k}_{-3}=1 \mathrm{~s}^{-1}$, specific activity $120 \mathrm{Ci} / \mathrm{mmol}$, assay volume $0.4 \mathrm{~mL}, \mathrm{C}=2.22 \cdot 10^{12}$ 
Table 3. Kinetic parameters for the association of PD81723 at the adenosine $A_{1}$ receptor

\begin{tabular}{cc}
\hline Kinetic & Value \\
constant & 1 \\
\hline $\mathrm{k}_{5}$ & $1 \times 10^{2} \mathrm{M}^{-1} \mathrm{~s}^{-}$ \\
$\mathrm{k}_{6}$ & $1 \times 1 \times 10^{-2} \mathrm{~s}^{-1} \mathrm{M}^{-1} \mathrm{~s}^{-}$ \\
$\mathrm{k}_{7}$ & 1 \\
$\mathrm{k}_{8}$ & $3 \times 10^{0} \mathrm{~s}^{-1}$ \\
$\mathrm{k}_{11}$ & $1 \times 10^{6} \mathrm{M}^{-1} \mathrm{~s}^{-}$ \\
& 1 \\
$\mathrm{k}_{12}$ & $3,4 \times 10^{1} \mathrm{~s}^{-1}$ \\
\hline
\end{tabular}


Table 4. Thermodynamic parameters for the binding of PD81723 at the adenosine $A_{1}$ receptor

\begin{tabular}{cc}
\hline Thermodynamic constant & Value \\
\hline $\mathrm{K}_{3}$ & $3,4 \times 10^{-5} \mathrm{M}$ \\
$\mathrm{K}_{4}$ & $7,7 \times 10^{-6} \mathrm{M}$ \\
$\mathrm{K}_{5}$ & $3 \times 10^{-6} \mathrm{M}$ \\
\hline
\end{tabular}


Table 5. Comparison between ECAM model and CK model

\begin{tabular}{lcc}
\hline & ECAM & CK \\
& model & model \\
\cline { 2 - 3 } It takes into account the different sites & No & Yes \\
an allosteric modulator A binds to & & \\
Number of equilibria involved in the model & 4 & 7 \\
Number of parameters required in the relevant equation & 4 & 5 \\
It is able to fit bell-shaped curves & Yes & Yes \\
It is able to fit very steep curves & Yes & Yes \\
\hline
\end{tabular}




\section{Appendix}

1. Derivation of a model for binding equilibrium

According to the scheme reported in Fig. 2:

$\mathrm{R}$ is a receptor,

$\mathrm{L}$ is a radioligand,

$\mathrm{A}$ is an allosteric modulator,

$\mathrm{G}$ is a G-protein,

$\mathrm{RL}$ is a receptor-radioligand complex,

GR is a G-protein-receptor complex,

RA is a receptor-allosteric modulator complex,

GRL is a G-protein-receptor-radioligand complex,

RLA is a receptor-radioligand-allosteric modulator complex,

$\mathrm{RA}_{2}$ is a complex between the receptor and two molecules of allosteric modulator,

GRA is a G-protein-receptor-allosteric modulator complex,

GRLA is a G-protein-receptor-radioligand-allosteric modulator complex,

GRA $_{2}$ is a complex between G-protein, receptor and two molecules of allosteric modulator;

the concentrations of the above species are represented by [ ].

The equilibria established within the system are the following:

$$
\mathrm{K}_{1}=\frac{[\mathrm{R}][\mathrm{L}]}{[\mathrm{RL}]}
$$


$\mathrm{K}_{2}=\frac{[\mathrm{R}][\mathrm{A}]}{[\mathrm{RA}]}$

(Eq. 2)

$\mathrm{K}_{3}=\frac{[\mathrm{RA}][\mathrm{A}]}{\left[\mathrm{RA}_{2}\right]}$

(Eq. 3)

$\mathrm{K}_{4}=\frac{[\mathrm{RL}][\mathrm{A}]}{[\mathrm{RLA}]}$

(Eq. 4)

$\mathrm{K}_{5}=\frac{[\mathrm{G}][\mathrm{R}]}{[\mathrm{GR}]}$

(Eq. 5)

$\alpha \mathrm{K}_{1}=\frac{[\mathrm{GR}][\mathrm{L}]}{[\mathrm{GRL}]}$

(Eq. 6)

$\beta \mathrm{K}_{2}=\frac{[\mathrm{GR}][\mathrm{A}]}{[\mathrm{GRA}]}$

(Eq. 7)

$\gamma \mathrm{K}_{3}=\frac{[\mathrm{GRA}][\mathrm{A}]}{\left[\mathrm{GRA}_{2}\right]}$

(Eq. 8)

$\delta \mathrm{K}_{4}=\frac{[\mathrm{GRL}][\mathrm{A}]}{[\mathrm{GRLA}]}$

(Eq. 9)

$\alpha \mathrm{K}_{5}=\frac{[\mathrm{G}][\mathrm{RL}]}{[\mathrm{GRL}]}$

(Eq. 10) 
$\beta \mathrm{K}_{5}=\frac{[\mathrm{G}][\mathrm{RA}]}{[\mathrm{GRA}]}$

(Eq. 11)

$\gamma \beta \mathrm{K}_{5}=\frac{[\mathrm{G}]\left[\mathrm{RA}_{2}\right]}{\left[\mathrm{GRA}_{2}\right]}$

(Eq. 12)

$\delta \alpha \mathrm{K}_{5}=\frac{[\mathrm{G}][\mathrm{RLA}]}{[\mathrm{GRLA}]}$

(Eq. 13)

After rearrangement of Eqs. 1 and 2, the following equations are obtained:

$[\mathrm{RL}]=\frac{[\mathrm{R}][\mathrm{L}]}{\mathrm{K}_{1}}$

$[\mathrm{RA}]=\frac{[\mathrm{R}][\mathrm{A}]}{\mathrm{K}_{2}}$

(Eq. 15)

By substitutions of [RL] from Eq. 14 into Eq. 4 and [RA] from Eq. 15 into Eq. 3, after further rearrangement, the following equations are obtained:

$$
\begin{aligned}
& {[\mathrm{RLA}]=\frac{[\mathrm{RL}][\mathrm{A}]}{\mathrm{K}_{4}}=\frac{[\mathrm{R}][\mathrm{L}][\mathrm{A}]}{\mathrm{K}_{1} \mathrm{~K}_{4}}} \\
& {\left[\mathrm{RA}_{2}\right]=\frac{[\mathrm{RA}][\mathrm{A}]}{\mathrm{K}_{3}}=\frac{[\mathrm{R}][\mathrm{A}]^{2}}{\mathrm{~K}_{2} \mathrm{~K}_{3}}}
\end{aligned}
$$

By rearrangement of Eq. 5 the following equation is obtained: 
$[\mathrm{GR}]=\frac{[\mathrm{G}][\mathrm{R}]}{\mathrm{K}_{5}}$

By substitution of [GR] from Eq. 18 into Eqs. 6 and 7, and rearranging them it is possible to obtain, respectively:

$[\mathrm{GRL}]=\frac{[\mathrm{G}][\mathrm{R}][\mathrm{L}]}{\alpha \mathrm{K}_{1} \mathrm{~K}_{5}}$

$[\mathrm{GRA}]=\frac{[\mathrm{G}][\mathrm{R}][\mathrm{A}]}{\beta \mathrm{K}_{2} \mathrm{~K}_{5}}$

(Eq. 20)

By substitution of [GRA] from Eq. 20 into Eq. 8 and [GRL] from Eq. 19 into Eq. 9, after suitable rearrangements, the following equations are obtained:

$\left[\mathrm{GRA}_{2}\right]=\frac{[\mathrm{GRA}][\mathrm{A}]}{\gamma \mathrm{K}_{3}}=\frac{[\mathrm{G}][\mathrm{R}][\mathrm{A}]^{2}}{\beta \gamma \mathrm{K}_{2} \mathrm{~K}_{3} \mathrm{~K}_{5}}$

$[\mathrm{GRLA}]=\frac{[\mathrm{GRL}][\mathrm{A}]}{\delta \mathrm{K}_{4}}=\frac{[\mathrm{G}][\mathrm{R}][\mathrm{L}][\mathrm{A}]}{\alpha \delta \mathrm{K}_{1} \mathrm{~K}_{4} \mathrm{~K}_{5}}$

Taking into account the law of conservation of mass, the total concentration of the receptor is given by:

$[\mathrm{R}]_{\mathrm{T}}=[\mathrm{R}]+[\mathrm{RL}]+[\mathrm{RA}]+\left[\mathrm{RA}_{2}\right]+[\mathrm{RLA}]+[\mathrm{GR}]$

$+[\mathrm{GRL}]+[\mathrm{GRA}]+\left[\mathrm{GRA}_{2}\right]+[\mathrm{GRLA}]$ 
where $[R]_{T}$ is the total concentration of the receptor and the terms on the right side of Eq. 23 represent the receptor in its different forms, i.e., bound to G-protein, radioligand, and allosteric modulator.

The terms in the right side of Eq. 23 can be substituted based on Eqs. 14, 15, 16, 17, 18, 19, 20, 21 and 22, to give, after rearrangement, the following equation:

$[\mathrm{R}]=\frac{[\mathrm{R}]}{\left\{\left[1+\frac{[\mathrm{L}]}{\mathrm{K}_{1}}\left(1+\frac{[\mathrm{A}]}{\mathrm{K}_{4}}\right)+\frac{[\mathrm{A}]}{\mathrm{K}_{2}}\left(1+\frac{[\mathrm{A}]}{\mathrm{K}_{3}}\right)\right]+\frac{[\mathrm{G}]}{\mathrm{K}_{5}}\left[1+\frac{[\mathrm{L}]}{\alpha \mathrm{K}_{1}}\left(1+\frac{[\mathrm{A}]}{\delta \mathrm{K}_{4}}\right)+\frac{[\mathrm{A}]}{\beta \mathrm{K}_{2}}\left(1+\frac{[\mathrm{A}]}{\gamma \mathrm{K}_{3}}\right)\right]\right\}}$ 24)

The revealed signal consists of the radioactivity associated with the receptor, that may be expressed as follows:

$\mathrm{S}=([\mathrm{RL}]+[\mathrm{RLA}]+[\mathrm{GRL}]+[\mathrm{GRLA}]) \cdot \mathrm{V}_{\mathrm{assay}} \cdot \mathrm{SA} \cdot \mathrm{C}$

where $\mathrm{V}_{\text {assay }}$ is the volume of the assay, $\mathrm{SA}$ is the specific activity of the radioligand and $\mathrm{C}$ is a proportionality constant. When the signal $\mathrm{S}$ is expressed in dpm, $\mathrm{V}_{\text {assay }}$ in $\mathrm{ml}, \mathrm{SA}$ in $\mathrm{Ci} / \mathrm{mmol}$ and the concentration of all the species present in the system is a molar concentration, then $\mathrm{C}=2.22 \times 10^{12}$.

By suitable substitutions from Eqs. 14, 16, 19 and 22 into Eq. 25, rearrangement, the following equation is obtained: 


$$
\mathrm{S}=[\mathrm{R}] \frac{[\mathrm{L}]}{\mathrm{K}_{1}}\left[1+\frac{[\mathrm{A}]}{\mathrm{K}_{4}}+\frac{[\mathrm{G}]}{\alpha \mathrm{K}_{5}}\left(1+\frac{[\mathrm{A}]}{\delta \mathrm{K}_{4}}\right)\right] \cdot \mathrm{V}_{\text {assay }} \cdot \mathrm{SA} \cdot \mathrm{C}
$$

In the experimental conditions of interest usually the following hypotheses are valid:

$[\mathrm{L}]_{\mathrm{T}}>>[\mathrm{R}]_{\mathrm{T}}$, where $[\mathrm{L}]_{\mathrm{T}}$ is the total concentration of the ligand;

$[G]_{T} \gg[R]_{T}$, where $[G]_{T}$ is the total concentration of the G-protein; and

$[A]_{T}>[R]_{T}$, where $[A]_{T}$ is the total concentration of the allosteric modulator;

where $>>$ means at least 10 times, preferably 100 times, further better 1,000 times and optimally more than 1,000 times.

Under the above conditions, the following equation is obtained:

$$
\mathrm{S}=\frac{[\mathrm{R}]_{\mathrm{T}} \frac{[\mathrm{L}]_{\mathrm{T}}}{\mathrm{K}_{1}}\left[1+\frac{[\mathrm{A}]_{\mathrm{T}}}{\mathrm{K}_{4}}+\frac{[\mathrm{G}]_{\mathrm{T}}}{\alpha \mathrm{K}_{5}}\left(1+\frac{[\mathrm{A}]_{\mathrm{T}}}{\delta \mathrm{K}_{4}}\right)\right] \cdot \mathrm{V}_{\text {assay }} \cdot \mathrm{SA} \cdot \mathrm{C}}{\left\{\left[1+\frac{[\mathrm{L}]_{\mathrm{T}}}{\mathrm{K}_{1}}\left(1+\frac{[\mathrm{A}]_{\mathrm{T}}}{\mathrm{K}_{4}}\right)+\frac{[\mathrm{A}]_{\mathrm{T}}}{\mathrm{K}_{2}}\left(1+\frac{[\mathrm{A}]_{\mathrm{T}}}{\mathrm{K}_{3}}\right)\right]+\frac{[\mathrm{G}]_{\mathrm{T}}}{\mathrm{K}_{5}}\left[1+\frac{[\mathrm{L}]_{\mathrm{T}}}{\alpha \mathrm{K}_{1}}\left(1+\frac{[\mathrm{A}]_{\mathrm{T}}}{\delta \mathrm{K}_{4}}\right)+\frac{[\mathrm{A}]_{\mathrm{T}}}{\beta \mathrm{K}_{2}}\left(1+\frac{[\mathrm{A}]_{\mathrm{T}}}{\gamma \mathrm{K}_{3}}\right)\right]\right\}}
$$

This equation shows the behavior of the system drawn in Fig. 1, under non-depletion conditions of radioligand, G-protein and allosteric modulator, in equilibrium radioligand binding experiments. However, if the receptor is completely dissociated from G-protein (Fig. 1B), Eq. 27 can be reduced to the following:

$$
\mathrm{S}=\frac{[\mathrm{R}]_{\mathrm{T}} \frac{[\mathrm{L}]_{\mathrm{T}}}{\mathrm{K}_{1}}\left(1+\frac{[\mathrm{A}]_{\mathrm{T}}}{\mathrm{K}_{4}}\right) \cdot \mathrm{V}_{\text {assay }} \cdot \mathrm{SA} \cdot \mathrm{C}}{\left[1+\frac{[\mathrm{L}]_{\mathrm{T}}}{\mathrm{K}_{1}}\left(1+\frac{[\mathrm{A}]_{\mathrm{T}}}{\mathrm{K}_{4}}\right)+\frac{[\mathrm{A}]_{\mathrm{T}}}{\mathrm{K}_{2}}\left(1+\frac{[\mathrm{A}]_{\mathrm{T}}}{\mathrm{K}_{3}}\right)\right]}
$$


On the other hand, when the receptor is completely associated to G-protein (Fig. 1C), Eq. 27 becomes:

$$
\mathrm{S}=\frac{[\mathrm{GR}]_{\mathrm{T}} \frac{[\mathrm{L}]_{\mathrm{T}}}{\alpha \mathrm{K}_{1}}\left(1+\frac{[\mathrm{A}]_{\mathrm{T}}}{\delta \mathrm{K}_{4}}\right) \cdot \mathrm{V}_{\text {assay }} \cdot \mathrm{SA} \cdot \mathrm{C}}{\left[1+\frac{[\mathrm{L}]_{\mathrm{T}}}{\alpha \mathrm{K}_{1}}\left(1+\frac{[\mathrm{A}]_{\mathrm{T}}}{\delta \mathrm{K}_{4}}\right)+\frac{[\mathrm{A}]_{\mathrm{T}}}{\beta \mathrm{K}_{2}}\left(1+\frac{[\mathrm{A}]_{\mathrm{T}}}{\gamma \mathrm{K}_{3}}\right)\right]}
$$

where $[\mathrm{GR}]_{\mathrm{T}}$ is the total concentration of receptor bound to the G-protein. Equations 27, 28, and 29 were inputed into the GraphPAD Prism software (GraphPAD, San Diego, CA, USA) and several simulations were carried out. It was accomplished by changing attempt values, chosen according to reasonable combinations, for those parameters, which usually require to be extracted from experimental data, just by exploiting suitable models previously developed.

\section{Derivation of a kinetic binding model}

The derivation of the kinetic model has been carried out for the system represented in Fig. 3. Such a scheme is aimed at illustrating a radioligand binding dissociation experiment, in which dissociation is induced by a ligand I present in high concentrations (Fig. 3A), and a radioligand binding association experiment (Fig. 3B). The association process represented in Fig. 3B is analogous to the one analyzed at the equilibrium and represented in Fig. 2B. The dissociation process represented in Fig. 3A comprises another species, I, which competes with the radioligand L and may be modulated by the allosteric modulator $\mathrm{A}$, when interacting with the receptor, giving so rise to the species 
RIA. Such a scheme may be described by the following set of ordinary differential equations (ODEs) and non-linear algebraic equations (NAEs).

$$
\begin{aligned}
& {\left[\mathrm{R}_{\mathrm{T}}=[\mathrm{R}]+[\mathrm{RL}]+[\mathrm{RA}]+\left[\mathrm{RA}_{2}\right]+[\mathrm{RLA}]+[\mathrm{RI}]+[\mathrm{RIA}]\right.} \\
& {[\mathrm{L}]_{\mathrm{T}}=[\mathrm{L}]+[\mathrm{RL}]+[\mathrm{RLA}]} \\
& {[\mathrm{A}]_{\mathrm{T}}=[\mathrm{A}]+[\mathrm{RA}]+[\mathrm{RLA}]+[\mathrm{RIA}]+2\left[\mathrm{RA}_{2}\right]} \\
& {[\mathrm{I}]_{\mathrm{T}}=[\mathrm{I}]+[\mathrm{RI}]+[\mathrm{RIA}]} \\
& \mathrm{v}_{1}=\mathrm{k}_{1}[\mathrm{R}] \cdot[\mathrm{L}] \\
& \mathrm{v}_{-1}=\mathrm{k}_{-1}[\mathrm{RL}] \\
& \mathrm{v}_{2}=\mathrm{k}_{2}[\mathrm{R}] \cdot[\mathrm{A}] \\
& \mathrm{v}_{-2}=\mathrm{k}_{-2}[\mathrm{RA}] \\
& \mathrm{v}_{3}=\mathrm{k}_{3}[\mathrm{RA}] \cdot[\mathrm{A}] \\
& \mathrm{v}_{-3}=\mathrm{k}_{-3}\left[\mathrm{RA}{ }_{2}\right] \\
& \mathrm{v}_{4}=\mathrm{k}_{4}[\mathrm{RL}] \cdot[\mathrm{A}] \\
& \mathrm{v}_{-4}=\mathrm{k}_{-4}[\mathrm{RLA}] \\
& \mathrm{v}_{6}=\mathrm{k}_{6}[\mathrm{R}] \cdot[\mathrm{I}] \\
& \mathrm{v}_{-6}=\mathrm{k}_{-6}[\mathrm{RI}] \\
& \mathrm{v}_{7}=\mathrm{k}_{7}[\mathrm{RI}] \cdot[\mathrm{A}] \\
& \mathrm{v}_{-7}=\mathrm{k}_{-7}[\mathrm{RIA}] \\
& \mathrm{dt}[\mathrm{RL}] \\
& \mathrm{dt}=\mathrm{v}_{1}-\mathrm{v}_{-1}-\mathrm{v}_{4}+\mathrm{v}_{-4} \\
&
\end{aligned}
$$




$$
\begin{aligned}
& \frac{\mathrm{d}\left[\mathrm{RA}_{2}\right]}{\mathrm{dt}}=\mathrm{v}_{3}-\mathrm{v}_{-3} \\
& \frac{\mathrm{d}[\mathrm{RLA}]}{\mathrm{dt}}=\mathrm{v}_{4}-\mathrm{v}_{-4} \\
& \frac{\mathrm{d}[\mathrm{RI}]}{\mathrm{dt}}=\mathrm{v}_{6}-\mathrm{v}_{-6}-\mathrm{v}_{7}+\mathrm{v}_{-7} \\
& \frac{\mathrm{d}[\mathrm{RIA}]}{\mathrm{dt}}=\mathrm{v}_{7}-\mathrm{v}_{-7} \\
& \frac{\mathrm{d}[\mathrm{R}]}{\mathrm{dt}}=-\mathrm{v}_{1}+\mathrm{v}_{-1}-\mathrm{v}_{2}+\mathrm{v}_{-2}-\mathrm{v}_{6}+\mathrm{v}_{-6} \\
& \frac{\mathrm{d}[\mathrm{L}]}{\mathrm{dt}}=-\mathrm{v}_{1}+\mathrm{v}_{-1} \\
& \frac{\mathrm{d}[\mathrm{A}]}{\mathrm{dt}}=-\mathrm{v}_{2}+\mathrm{v}_{-2}-\mathrm{v}_{3}+\mathrm{v}_{-3}-\mathrm{v}_{4}+\mathrm{v}_{-4}-\mathrm{v}_{7}+\mathrm{v}_{-7} \\
& \frac{\mathrm{d}[\mathrm{I}]}{\mathrm{dt}}=-\mathrm{v}_{6}+\mathrm{v}_{-6} \\
& \mathrm{~S}=([\mathrm{RL}]+[\mathrm{RLA}]) \cdot \mathrm{v}_{\text {assay }} \cdot \mathrm{SA} \cdot \mathrm{C}
\end{aligned}
$$

In the above equations the kinetic constants are represented by $k_{n}$ and $k_{-n}$. All the species and variables involved in the above equations are the same as the ones described for the thermodynamic approach. In addition:

I is an inhibitor,

$\mathrm{RI}$ is a receptor-inhibitor complex,

RIA is a receptor-inhibitor-allosteric modulator complex,

As specified before, the concentrations of all the species are represented by [ ].

$[\mathrm{I}]_{\mathrm{T}}$ is the total concentration of the inhibitor.

The biological system described above was analyzed by using the DBsolve Optimum 
software (Goryanin et al., 1999). DBsolve Optimum is capable of accomplishing the wanted calculations by using properly implemented algorithms accurately describing models like the ones under examination. The algorithms handle solving procedures for ODE, NAE and mixed ODE/NAE systems. 

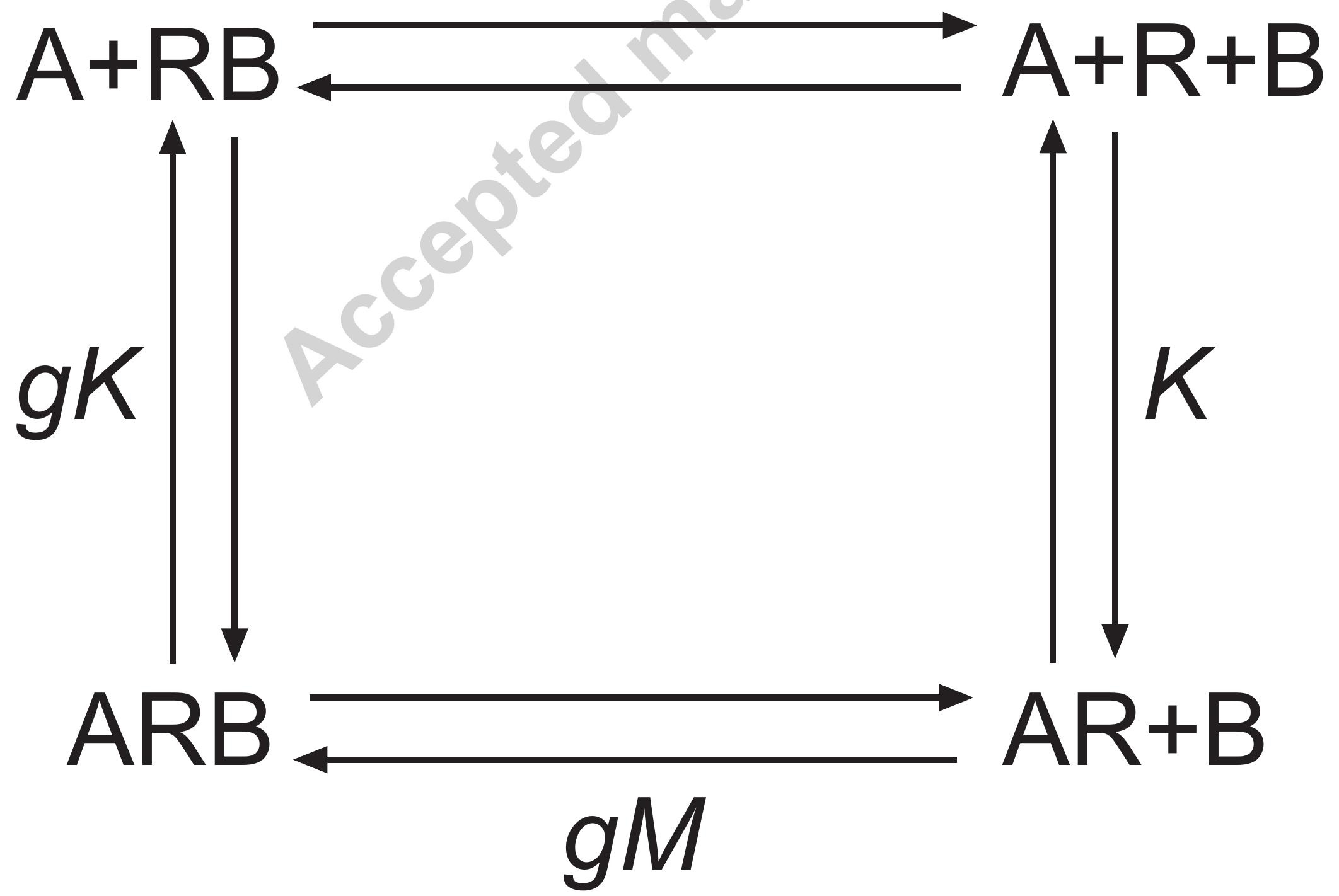
K

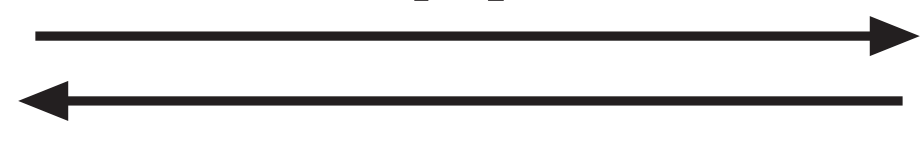

$\mathrm{HR}+\mathrm{G}$

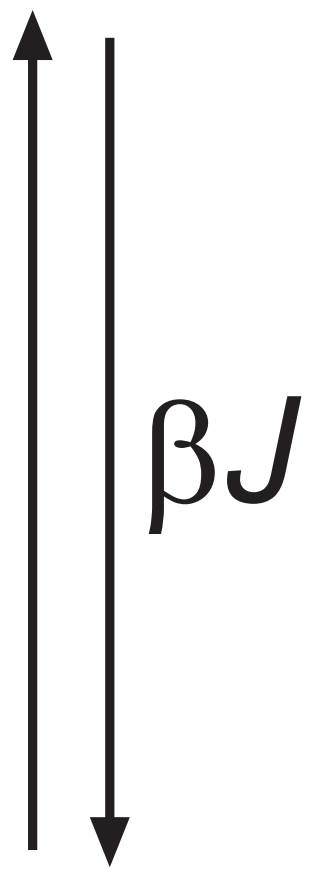

$\mathrm{HR}^{*}+\mathrm{G}$

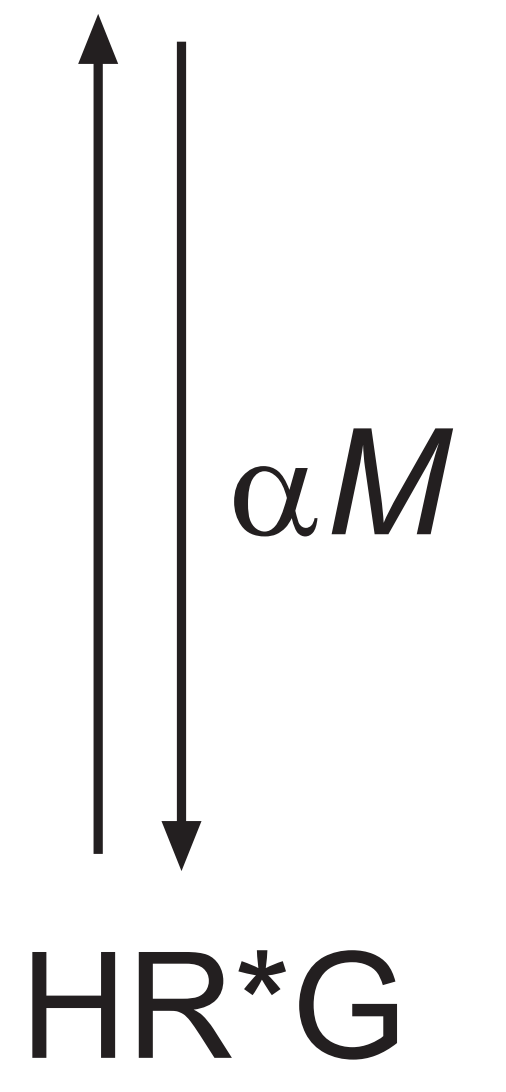

$\mathrm{HR}^{*} \mathrm{G}$

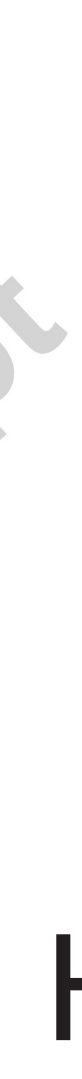

$\mathrm{H}+\mathrm{R}+\mathrm{G}$
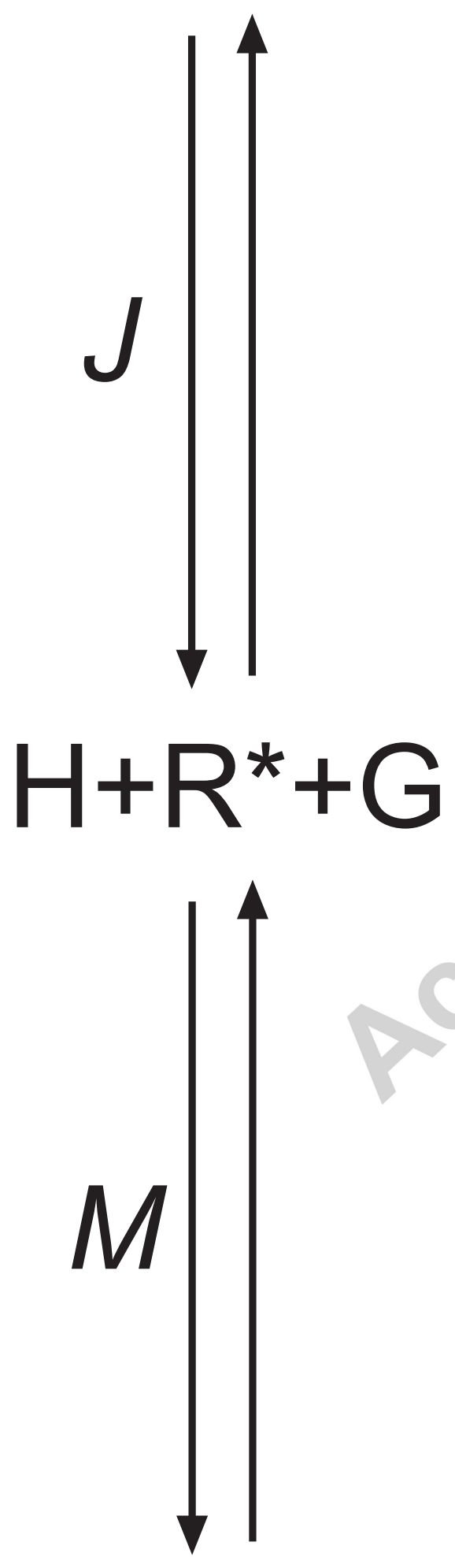

$H+R^{*} G$
$\mathrm{H}+\mathrm{R}^{*}+\mathrm{G}$

$\beta K$

$\alpha \beta K$
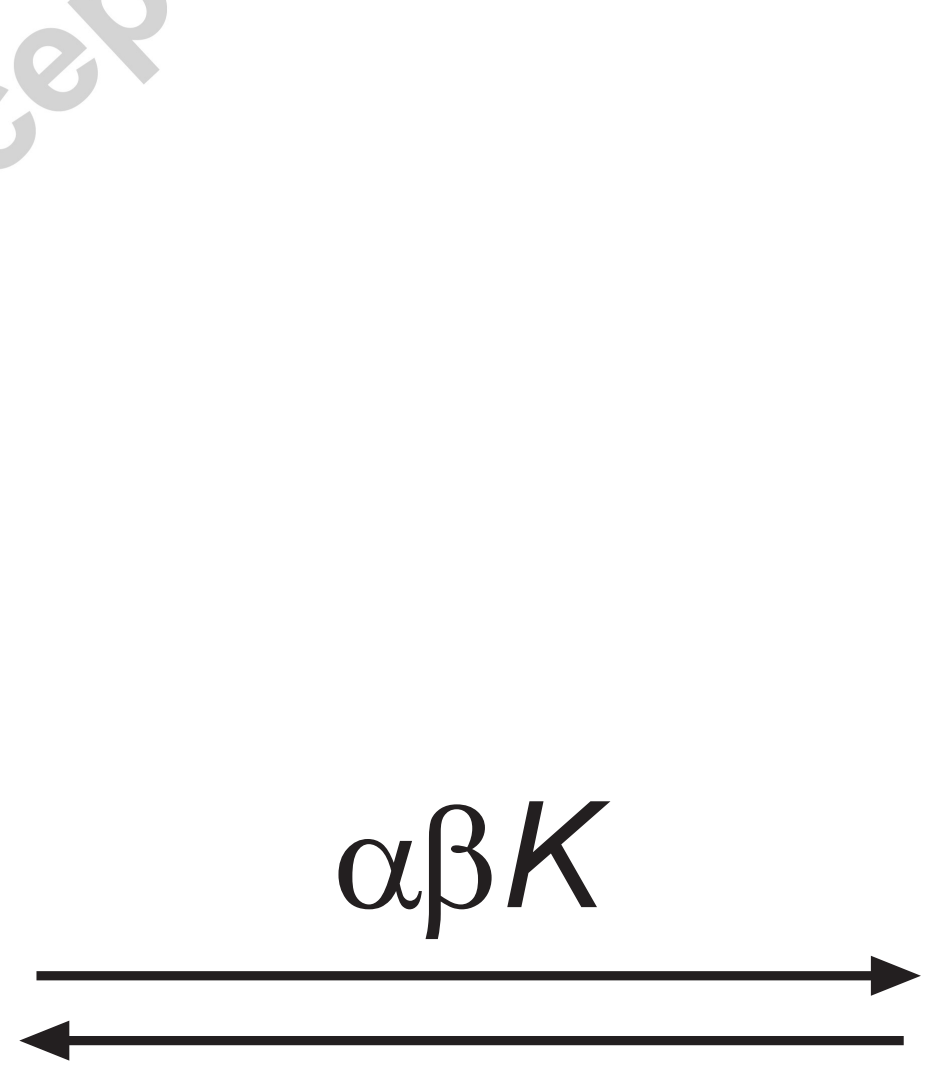
$\beta M$

$\mathrm{A}+\mathrm{B}+\mathrm{R}^{*} \rightleftarrows \mathrm{R}^{*} \mathrm{~B}+\mathrm{A}$ $\mathrm{A}+\mathrm{B}+\mathrm{R}$

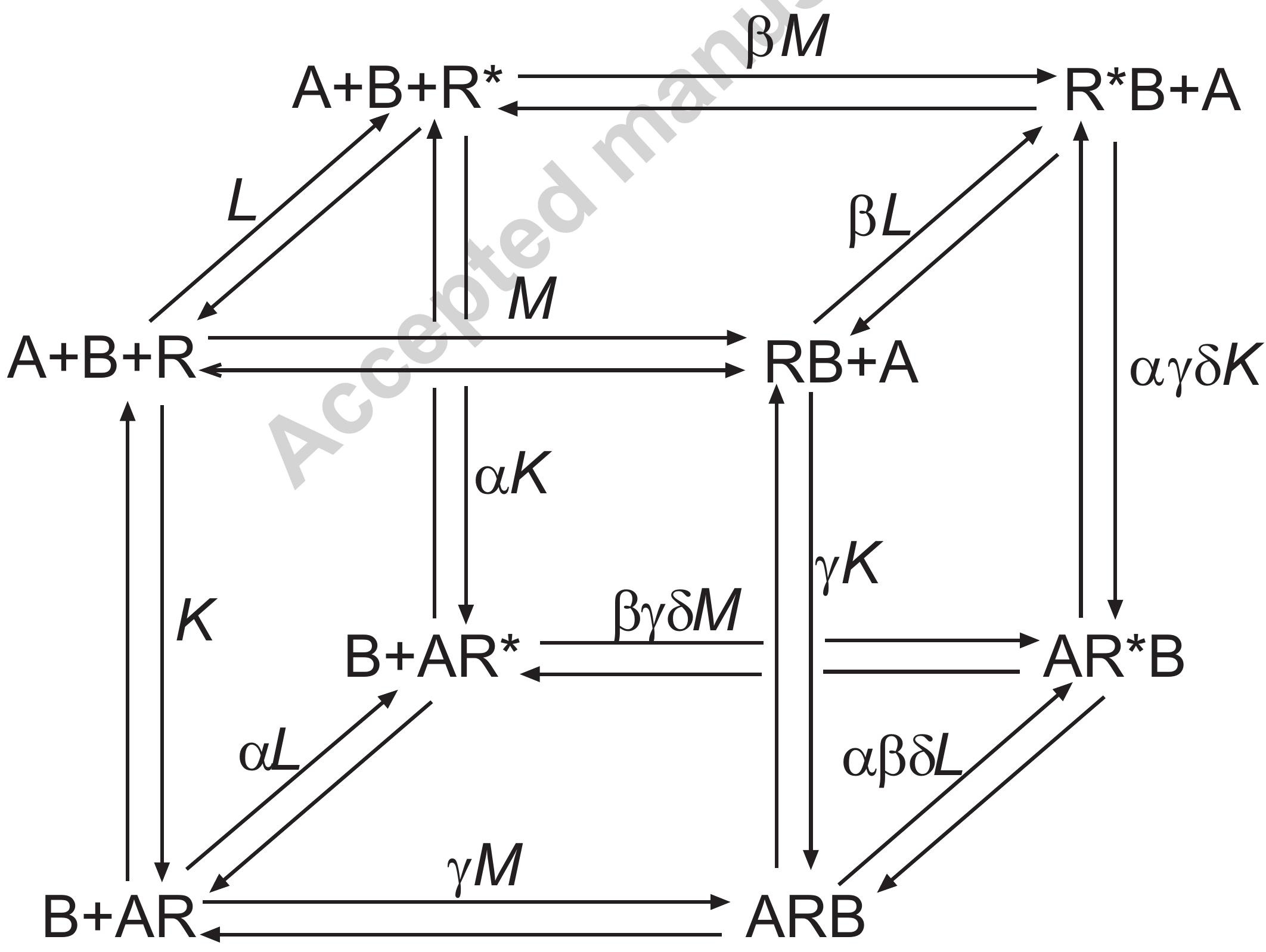

$\alpha \gamma \delta K$ 


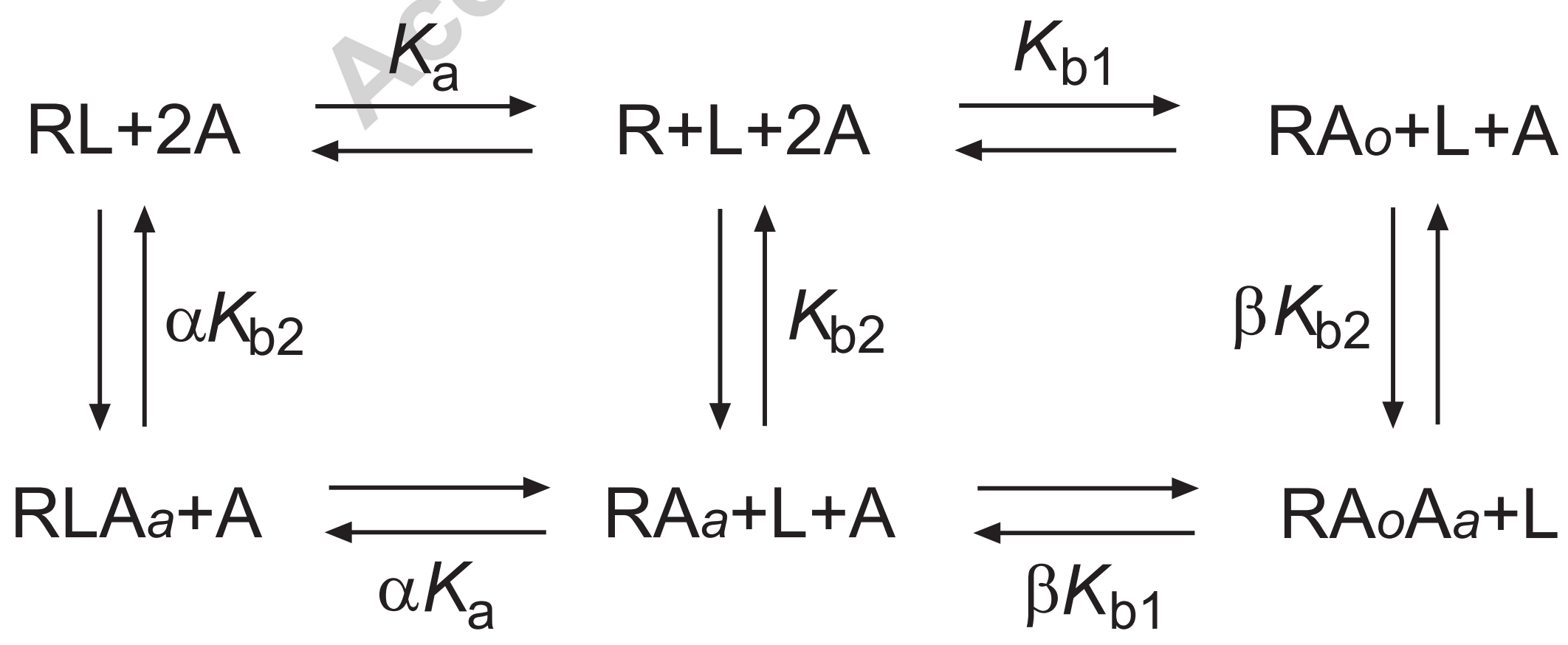

Figure 1d

$R+L+2 A$
$\mathrm{RL}+2 \mathrm{~A}$
$\mathrm{RA} o+\mathrm{L}+\mathrm{A}$

$\beta K_{\mathrm{b} 2} \mid \uparrow$ $\beta K_{\mathrm{b} 1}$ 

A
B
$\mathrm{G}+\mathrm{RA}_{2}+\mathrm{L} \stackrel{\mathrm{K}_{3}}{\rightleftarrows} \mathrm{G}+\mathrm{RA}+\mathrm{L}+\mathrm{A} \stackrel{\mathrm{K}_{2}}{\rightleftarrows} \mathrm{G}+\mathrm{R}+\mathrm{L}+2 \mathrm{~A} \stackrel{\mathrm{K}_{1}}{\Longleftrightarrow} \mathrm{G}+\mathrm{RL}+2 \mathrm{~A} \stackrel{\mathrm{K}_{4}}{\Longleftrightarrow} \mathrm{G}+\mathrm{RLA}+\mathrm{A}$
$\gamma \beta K_{5} \uparrow \mid$
$\beta K_{5} \uparrow \downarrow$
$\mathrm{K}_{5} \uparrow \downarrow$
$\alpha K_{5} \uparrow \downarrow$
$\delta \alpha K_{5}^{\uparrow} \mid$
C
$\mathrm{GRA}_{2}+\mathrm{L} \stackrel{\gamma \mathrm{K}_{3}}{\rightleftarrows} \mathrm{GRA}+\mathrm{L}+\mathrm{A} \stackrel{\beta \mathrm{K}_{2}}{\rightleftarrows} \mathrm{GR}+\mathrm{L}+2 \mathrm{~A} \stackrel{\alpha \mathrm{K}_{1}}{\rightleftarrows} \mathrm{GRL}+2 \mathrm{~A} \stackrel{\delta \mathrm{K}_{4}}{\rightleftarrows} \mathrm{GRLA}+\mathrm{A}$ 
A

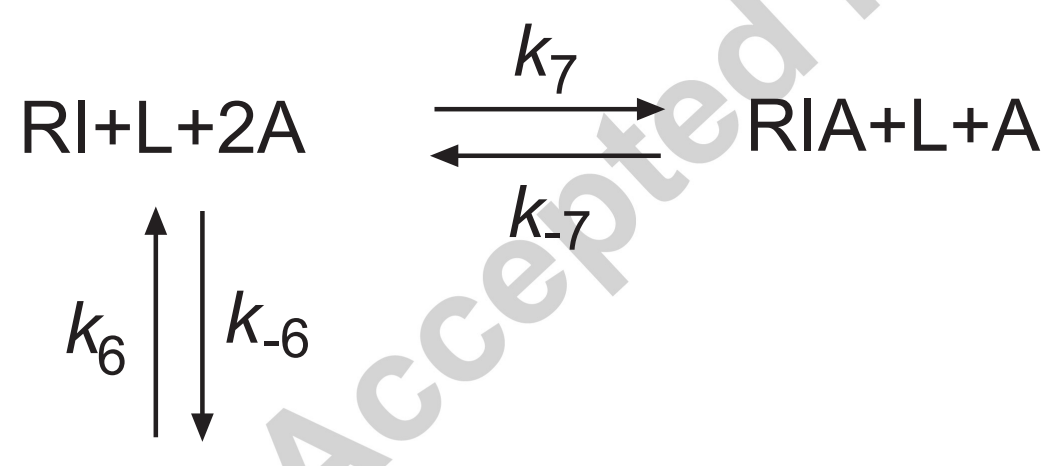

B

$$
\begin{array}{rl}
\mathrm{R}+\mathrm{L}+\mathrm{I}+2 \mathrm{~A} & \stackrel{k_{2}}{\rightleftarrows} \\
k_{-2} & \mathrm{RA}+\mathrm{L}+\mathrm{I}+\mathrm{A} \stackrel{k_{-3}}{\stackrel{k_{3}}{\rightleftarrows}} \mathrm{RA}_{2}+\mathrm{L}+\mathrm{I} \\
\mathrm{RL}+\mathrm{I}+2 \mathrm{~A} & \stackrel{k_{-1}}{\rightleftarrows}
\end{array}
$$


Figure 4

A

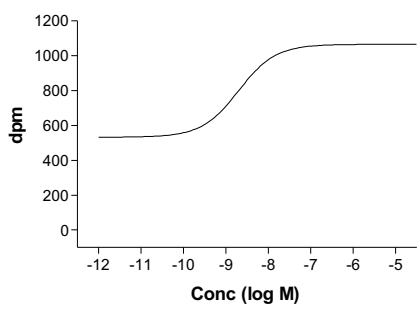

D

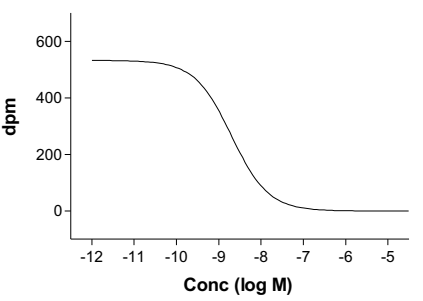

G

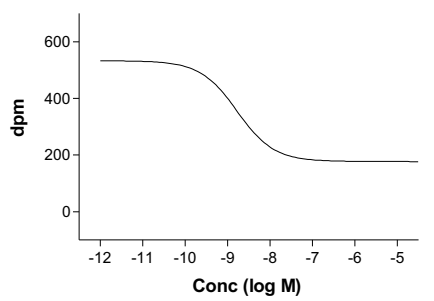

B

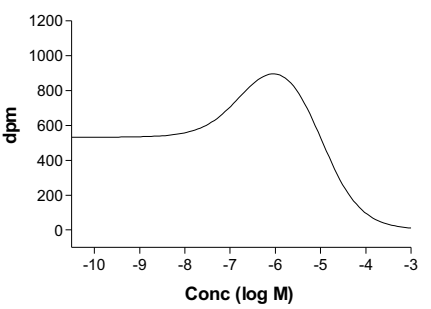

E

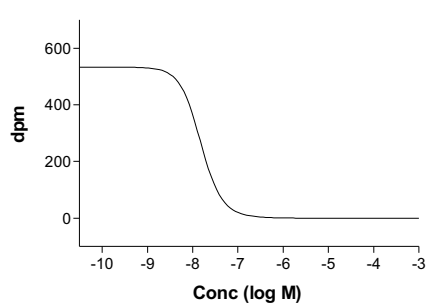

H

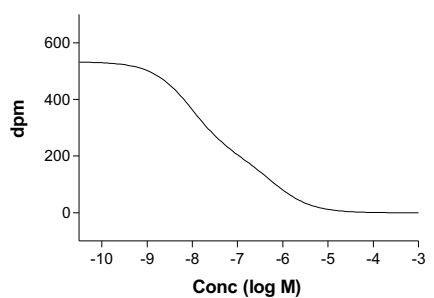

C

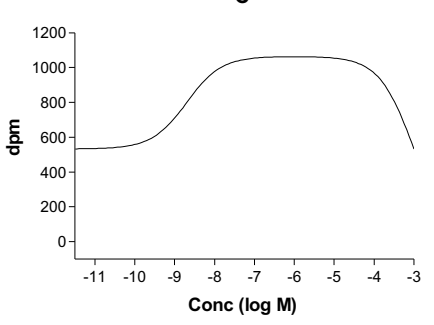

F

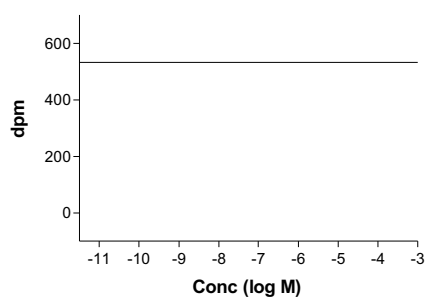

I

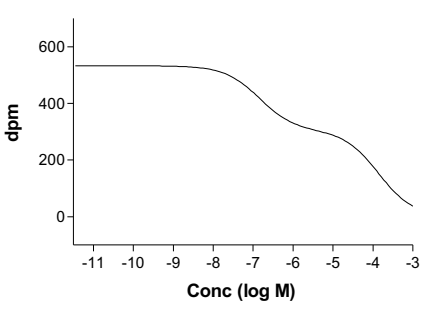




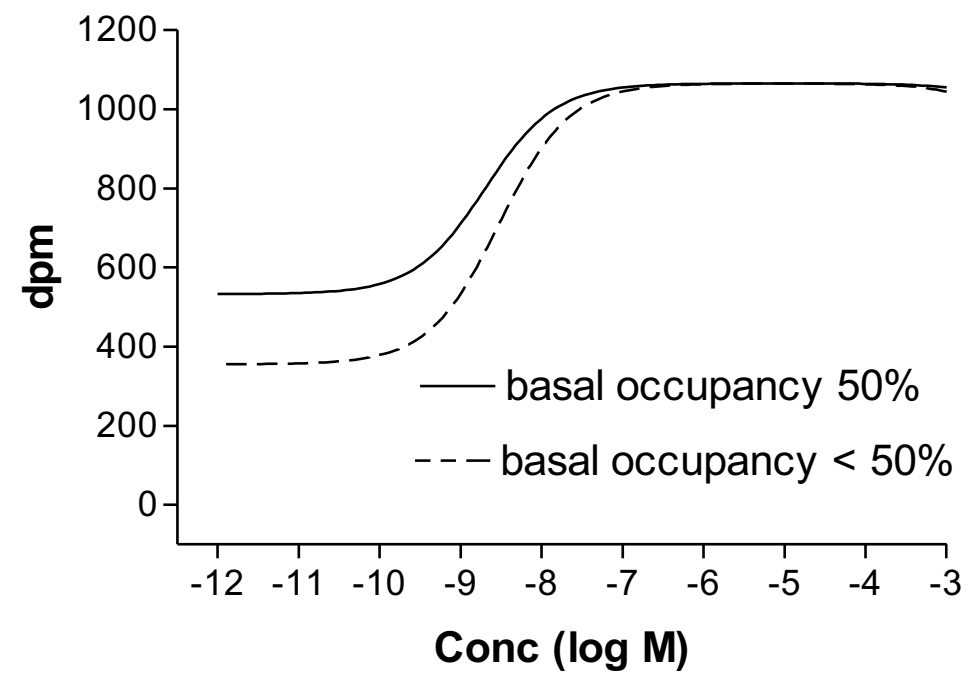




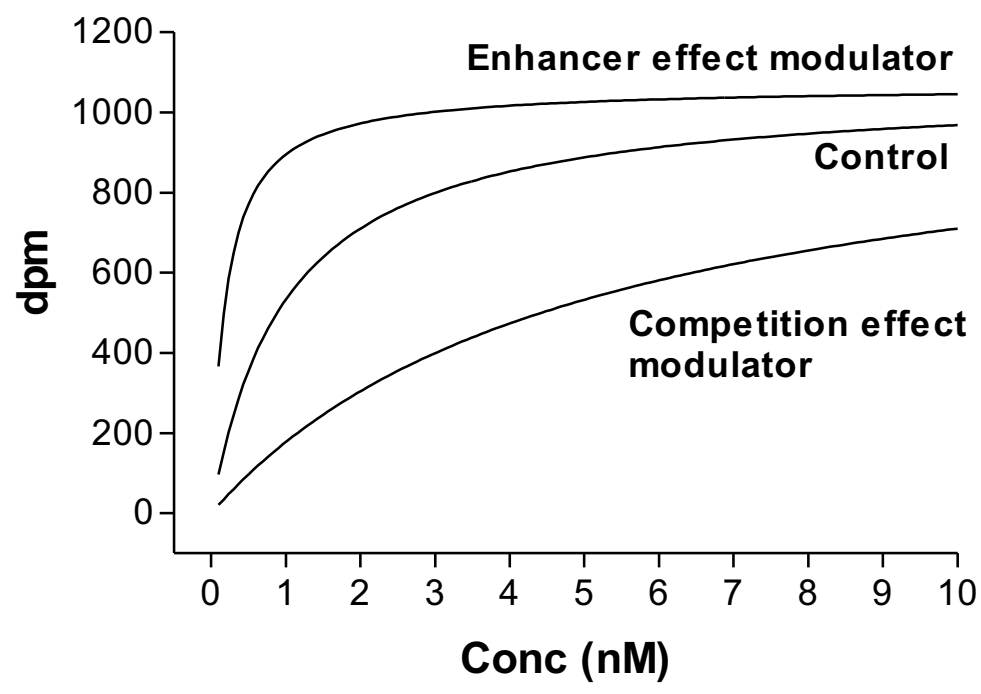




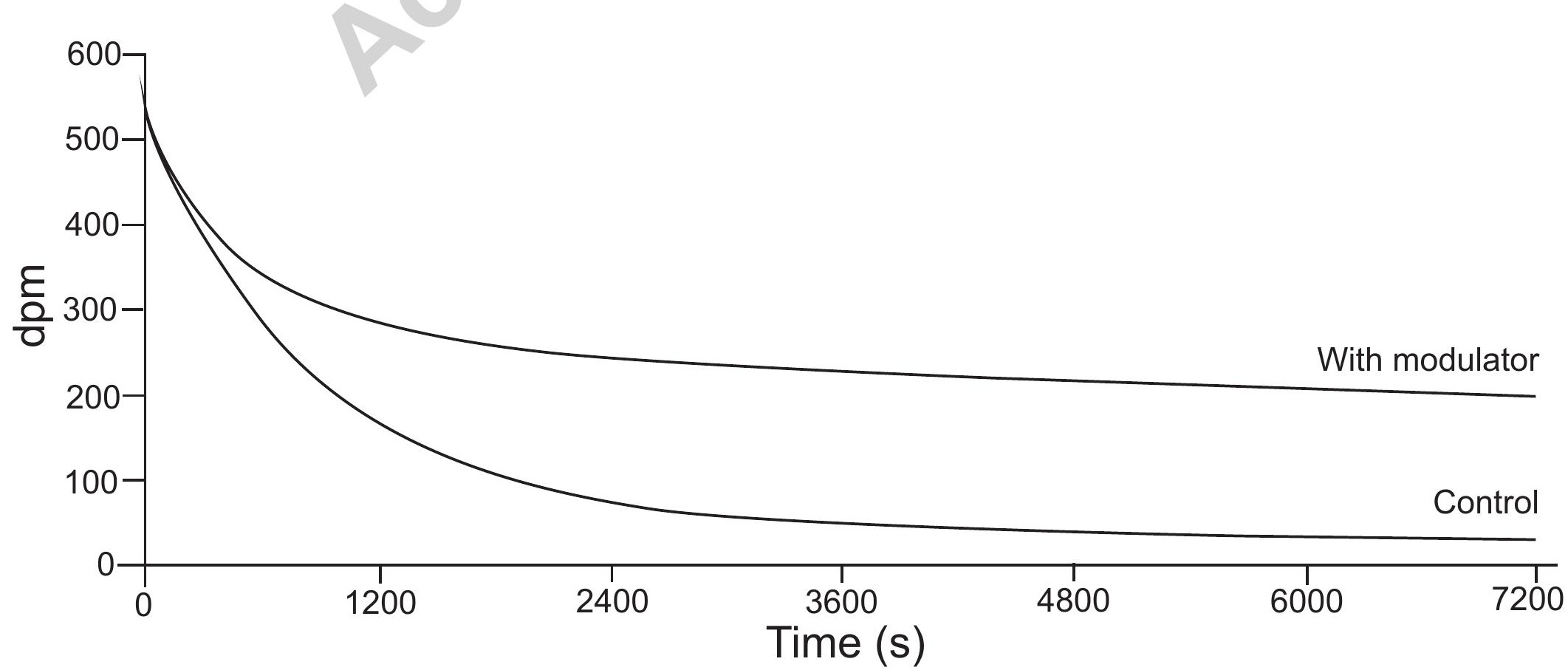



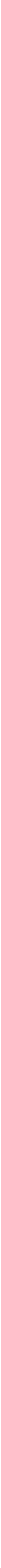
Figure 9

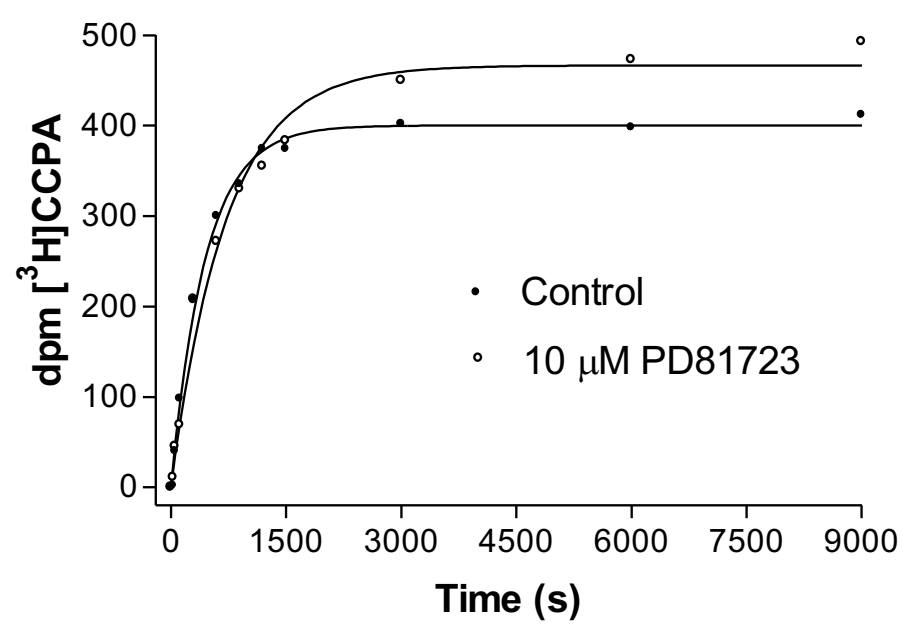




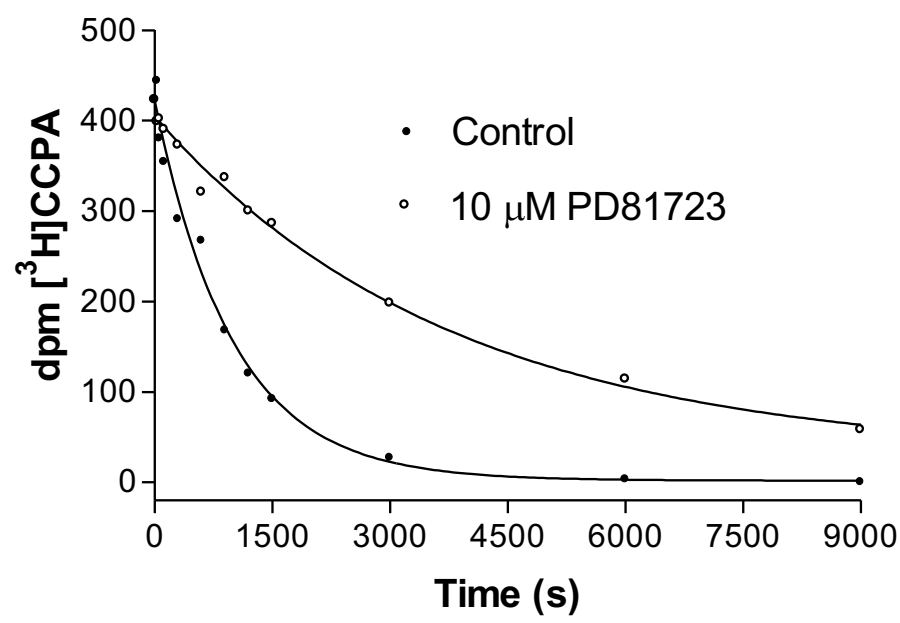




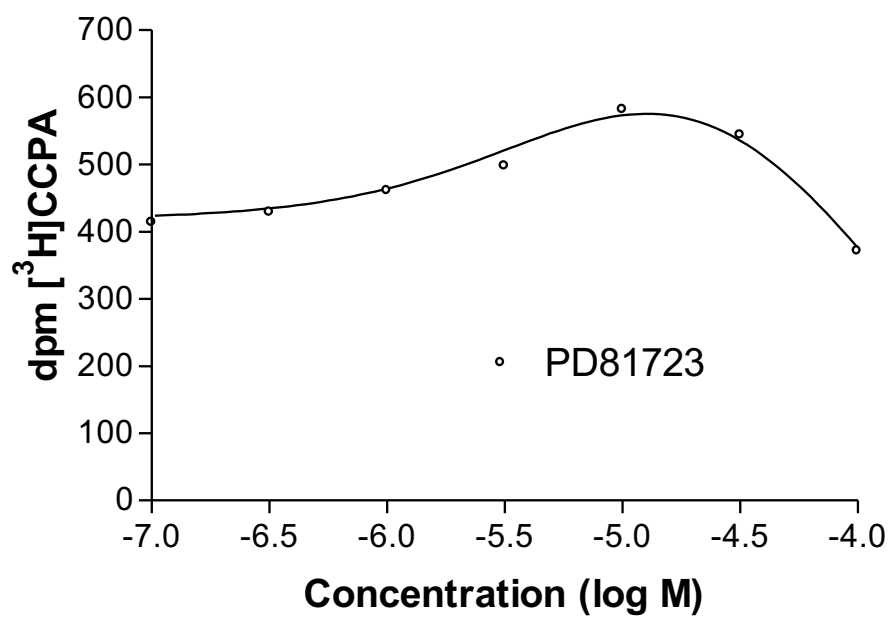




$$
\rho_{\mathrm{A}}=\frac{\frac{[\mathrm{A}]}{\mathrm{K}_{\mathrm{A}}}\left(1+\alpha[\mathrm{B}] / \mathrm{K}_{\mathrm{B} 2}\right)}{\frac{[\mathrm{A}]}{\mathrm{K}_{\mathrm{A}}}\left(1+\alpha[\mathrm{B}] / \mathrm{K}_{\mathrm{B} 2}\right)+\left[1+[\mathrm{B}] / \mathrm{K}_{\mathrm{B} 1}+[\mathrm{B}] / \mathrm{K}_{\mathrm{B} 2}\left(1+\beta[\mathrm{B}] / \mathrm{K}_{\mathrm{B} 1}\right)\right]}
$$


